\title{
PROJECT-BASED INDUSTRIES AND CRAFT-LIKE PRODUCTION: STRUCTURE, LOCATION, AND PERFORMANCE
}

\author{
Peter Doeringer* - doeringe@bu.edu \\ Pacey Foster** - pacey.foster@umb.edu \\ Stephan Manning** - Stephan.manning@umb.edu \\ David Terkla** - david.terkla@umb.edu \\ *Boston University; **University of Massachusetts Boston
}

Version July 2012

WORKING PAPER

\section{Full reference:}

Doeringer, P., Foster, P., Manning, S., Terkla, D. 2013. "Project-based industries and craft-like production: structure, location, and performance”, in: Giarratani, F., Hewings, G., McCann, P. (Eds.): Handbook of Industry Studies and Economic Geography. Edward Elgar, Cheltenham: 99151. ISBN: 978-1843769613. 


\section{Project-Based Industries and Craft-like Production: Structure, Location, and Performance}

Craft production, craft-based labor markets, and urban industrial districts were once central to the development of many U.S. industries in the early 19th century (Atack and Passell, 1994; Jackson, 1984; Jacoby, 1991). In manufacturing these industries included meat cutting, brewing, clothing, printing, iron mills, and various kinds of non-electrical machinery. Outside of manufacturing, craft production was common in the maritime industry and the railroads as well as in construction. Craft-like production and craft skills, however, were subsequently replaced by large-scale firms using less-skilled labor, mass production technologies, and new forms of work organization that could more efficiently serve emerging mass markets (Chandler, 1962; Atack and Passell, 1994, Chs. 1, 17; Stinchcombe, 1959). As these industries matured, however, growth slowed in the latter decades of the $20^{\text {th }}$ century and often reversed as global competition and the international product cycle resulted in the transfer of much of U.S. mass production offshore (Vernon, 1966; Dicken, 2011).

In an environment of debate about the future of industrial societies, Piore and Sabel, 1984) advanced the provocative concept of "flexible specialization" to describe a new manufacturing model for industrialized countries. The flexible specialization model was patterned after northern Italy's flourishing industrial districts, such as the textile design and manufacturing cluster Emilia Romagna, where manufacturing is characterized by a high degree of product variety, small firms, highly-skilled labor, fluid employment relationships, and overlapping work and social communities that promote industrial performance through trust and cooperation as well as competition. This form of "craft-like" flexible specialization was seen as the modern counterpart of 19th century craft production systems.

Flexible specialization presented a compelling logic for designing a new economic model where small-scale firms could serve smaller, more volatile, and less-certain markets by exploiting the comparative advantages typically held by developed countries -- advanced technologies, proximity to large industrial and consumer markets, educated and skilled labor, and the research and development capacity to produce innovative and high value-added products and in some cases by drawing upon the externalities of local pools of labor and entrepreneurial talent. However, this model has not taken hold to any significant degree in the United States manufacturing sector. Large firms have downsized, but they remain the dominant producers in 
most manufacturing industries; there is little evidence of a significant shift towards more fluid employment relationships (Copeland, 2010) despite major changes in the industrial and demographic composition of employment.

Craft-like production, however, occupies a dominant role in so-called 'project industries'. Project industries specialize in one-of-a kind and customized products and in small-batches of highly differentiated products. They often require a shifting mix of occupations and skills that must often be mobilized and coordinated on short notice by the firm that leads the project and project industries often rely on complex networks of collaborating contractors. Employment relationships are often temporary, lasting for all or a part of each project, but the lead firms typically retain a core group of employees and contractors with greater continuity of employment and greater knowledge of how to organize and conduct project-based production (e.g. Cicmil \& Hodgson, 2006; Whitley, 2006; Lundin \& Soederholm, 1995; Manning, 2008).

Project-based production is common for example in construction, motion pictures and videos, software development, consulting, complex system development (see e.g. Eccles, 1981; Hobday, 2000; DeFillippi \& Arthur, 1998; Grabher, 2004), as well as in manufacturing where examples range from prototype production for industrial and consumer products, to repeated cycles of small batches of innovation-based products (such as in fashion industries, advanced materials, biopharmaceuticals, and medical instruments), to one-of-a-kind samples and replacement parts supplied by small-scale machine shops (Hobday, 2000). Examples of projectbased production can even be found mass production industries such as autos, as illustrated by Midler's (1995) study of the tendency to “projectification” at Renault (Middler, 1995).

We posit that project-based production, rather than flexible specialization per se, represents an important and enduring production paradigm for developed countries in the $21 \mathrm{st}$ century (Cicmil \& Hodgson, 2006). Project-based firms in the United States have already established a track record for competing in global markets for products where scope economies, speed of production, and the ability to switch quickly from one project to another are more important than economies of scale, and they have also demonstrated a remarkable ability to adapt to changing market conditions and technologies. 
Project industries often cluster in districts or regions because of the skills and knowledge required in design and production, the specialized materials and services provided by suppliers, and the imperatives of staffing project production and coordinating contracting networks when speed and flexibility are of paramount importance. Examples are high-tech firms based in Silicon Valley whose project-based production systems have co-evolved with strong regional externalities related to pools of skilled labor, career mobility, and knowledge spillovers among firms (see e.g. Saxenian, 1996).

This interaction between project industries and regional externalities has not been lost on local and regional economic development efforts. For example, several states have begun focusing on attracting creative industry clusters and there has been increased focus on sectors of manufacturing, such as biopharmaceuticals and medical devices, which utilize project-based production practices. However, these state and local policies often treat these project-based industries in the same ways as they would other types of industry clusters, while neglecting the distinctive micro-foundations of project-based clusters and the types of regional externalities that they require.

For example, education, training, and job matching arrangements are often directed at larger employers that typically hire workers with relatively narrow skills and provide them with additional training as needed in skills that are relatively specific to the firm, rather than addressing the high skills and mobility needs of more-fluid labor markets organized horizontally by occupation that typically characterize product-based production (Tolbert, 1996). Similarly, few regional development efforts recognize the fine-grained organizational relationships between the internal capacities of the firms that "lead" project-based production and the myriad contractors that must be assembled and coordinated in order to meet the special production needs of one-of-a-kind and small batch products.

This chapter reviews the relatively sparse literature on the structure, conduct, and regional clustering of project-based industries followed by the more extensive micro-level literature on organizational and networking theories of project-based production. It then examines the organizational arrangements, internal employment systems, external labor market structures, labor-management practices, and regional externalities that define the project-based production paradigm. The chapter concludes with two case studies of project-based industries 
that provide concrete examples of the economic dynamics of such industries and their interaction with regional agglomeration advantages.

The first case examines the evolution of a traditional manufacturing industry with a relatively stable technology (women's wear) located in an industrial district (New York City) that has long provided substantial agglomeration externalities for women's wear manufacturing. Both the industry and the district have reached the mature stage of their life-cycles and are hoping to survive the challenges of global competition by returning to an earlier form of smallscale, project-based production combined with new types of district externalities.

The second case looks at a project-based information industry (motion pictures, television, and videos) that has traditionally been concentrated in Los Angeles and New York City, both of which are "creative" districts that have accumulated powerful externalities for serving the motion picture sector, television production, and related video industries (Christopherson et al., 2006; Christopherson and Storper, 1989). This industry has experienced significant changes in both its industrial structure and technology that have lessened the importance of some of the agglomeration economies that kept production in Los Angeles and New York and these districts are facing growing competition from other U.S. regions and other countries that are offering production subsidies in hopes of establishing viable "satellite" clusters of motion picture, television, and video production. The case study examines the initial experience in Massachusetts with creating an "infant" production region that would have sufficient cost and agglomeration advantages to compete for an industry that is beginning to decentralize to new locations in the United States and abroad.

Each of these cases illustrates a distinctive set of organizational arrangements for projectbased production and provides examples of how project-based industries improve their performance by creating and reinforcing regional production externalities. Collectively, the cases argue for the usefulness of studying economic development processes at the intersection of project-based industry and district externalities and for taking a fresh look at federal and state policies for strengthening industrial performance in the context of local and regional economic development.

\section{Districts, Clusters, and Project-based Production: A Review}


Alfred Marshall is the most widely-cited source for defining what makes an industrial district (Marshall, 1890). For Marshall, districts emerge when one or more key local externalities for firms are present: (1) human capital efficiencies from shared pools of labor with industrial skills and knowledge, (2) transaction efficiencies of communication and transportation from proximity to specialized suppliers and buyers, and (3) knowledge spillovers from production know-how, technological developments, and knowledge about customers and markets. These Marshallian externalities are freely available to firms that locate in the district and are reinforced as firms locate and expand in response to the availability of regional market externalities. However, firms are seen as "externality-takers", rather than externality "creators."

Subsequent research has extended our understanding of what makes a district by introducing the concept of a network of interdependencies among industry sectors (Chinitz, 1961) and documenting the externalities of organizational relationships and district cultures as further sources of efficiency advantage. For example, Italian garment districts are well-known for collaborative production relationships and sharing of knowledge among local suppliers (Brusco, 1982; Bigarelli, 2000; Bigarelli and Crestanello, 2004); Saxenian's "regional advantage" documented the role of regional business cultures in promoting knowledge spillovers (Saxenian, 1994); Porter (1994) emphasized the importance of active competition among spatiallyconcentrated clusters of firms; and the mediating role of social relationships among workers and entrepreneurs in facilitating the blending of active cooperation with active competition has also been highlighted (Piore and Sabel, 1984; Reid, Smith, and Caroll, 2008).

\section{Gaps in the Theory and Literature}

Major gaps remain in our understanding of industries that cluster, and of the districts that house such clusters. While we know that externalities and knowledge spillovers are critical elements of cluster performance, we do not know exactly how this happens and have little analysis of the internal organization of firms in relation to district development (Motoyama, 2008). Instead, there is a tendency to treat the clustering as a universal phenomenon, rather than recognizing the importance of industry-specific and region-specific conditions that are associated with particular aspects of cluster development (Doeringer and Terkla, 1995; Motoyama, 2008). 
The micro-foundations of Marshall's conception of externalities are rooted in the economics of atomistic markets in which individual firms have little independent influence on the formation of clusters and the development of the collective externalities of districts. Yet many modern districts are dominated by large firms, or by collective organizations (business associations of small firms, trade unions, and education and training institutions), that have considerable market power to shape local externalities (Giarratani, Gruver, and Jackson, 2007; Lundequist and Power, 2002; Doeringer, Evans, Terkla, 2002). Yet we know little about how strategic conduct and economic power affects clustering or the formation of district externalities.

Similarly, there has been insufficient exploration of the dynamic interactions between cluster development and district development -- why and where clusters first develop, how they evolve, and why regions with similar clusters perform differently (Feser, et al., 2008; Hill and Brennan, 2000; Montana and Nenide, 2008; Newlands, 2003). The few studies that exist are not enough to provide generalizations about the cluster development process (Feldman and Francis, 2004; Lundequist and Power, 2002; Motoyama, 2008). These gaps point to the need for longerterm studies of the origins and evolutionary paths of districts and their clusters of firms (Newlands, 2003).

\section{Project-based Production}

The literature that has comes closest to addressing these gaps examines the organizational forms, organizational relationships, and production practices in the context of "project-based production." Projects are generally defined as a "temporary endeavor undertaken to create a unique product or service" (PMI 2000:4) and project-based production is seen as an emerging paradigm that carries strong implications for U.S. industrial performance and competitiveness.

The key elements of project-based production -- time limitations, relative uniqueness and complexity, and the involvement of teams to accomplish project goals - require distinctive organizational forms, business practices, and organizational relationships (Lundin \& Soederholm, 1995; Manning, 2008). These characteristics are also important for understanding the tendency of project firms to form clusters in regions that offer externalities that are tailored to project production, rather than to mass production. 
The conventional economics literature has been largely silent about the role of project industries and project-based regional clusters in improving industrial performance and stimulating regional growth, although there have been a handful of notable exceptions in regional economics and economic geography (see e.g. Grabher, 2002a and 2002b; Sydow \& Staber, 2002) which have looked in particular at geographically concentrated 'project ecologies' around which creative industry clusters can form and be sustained. Project-based production has received considerable attention in a variety of other disciplines -- systems engineering, innovation, and organizational behavior (see e.g. Hobday, 2000; Whitley, 2006; Cicmil \& Hodgson, 2006; Grabher, 2002a).

One important aspect of this discussion is the relationship between flexible projects and the institutional context in which such production occurs. For example, using the case of cultural production, both Grabher (2002a) and Sydow \& Staber (2002) make the point that in order for projects to be regularly initiated within a region there must be a certain amount of "institutional thickness" embedded in interconnected local institutions, such as training and education organizations and funding institutions that can support project ideas, train professionals, and finance projects (Amin \& Thrift, 1994). Regional economic and organizational studies have also pointed at the equally important role of flexible labor markets within regions as a source of innovation, knowledge spillover, and longer-term career opportunities of project professionals (see e.g. Saxenian, 1996; Grabher, 2004).

Project-based production has also been studied in a number of industries including: film and TV production (e.g. Storper, 1989; Starkey et al., 2000; Windeler \& Sydow, 2001; Manning \& Sydow, 2011), advertising (Grabher, 2002b), theatre and other cultural production (Uzzi, 2004; Haunschild, 2003); event management (Pitsis et al., 2003); construction (Newcombe, 1996; Berggren et al., 2001; Stinchcombe, 1959); complex product and systems development (Hobday, 2000; Shenhar \& Dvir, 1996; Gann \& Salter, 2000); and research and consulting (Hagedoorn et al., 2000; Manning, 2010; Lash \& Wittel, 2002). Projects have also been recognized as the basis for important forms of production and business organization in various fields, including economic sociology and organization studies (e.g. Lundin \& Midler, 1998), innovation (e.g. Cicmil \& Hodgson, 2006), regional studies (e.g. Grabher, 2002a and 2002b), and engineering (Shenhar, 2001). A number of scholars have also observed an increasing 
penetration of project-based organizational forms across industries (see e.g. Soederlund, 2000; Midler, 1995). Reasons include the relative flexibility and capacity of projects - compared to more continuous, routine-based forms of production - to mobilize resources within and across organizational boundaries in complex and novel ways (see e.g. Asheim \& Mariussen, 2003).

In the organization and innovation literature, the focus of research has been largely on aspects of managing project-based production (e.g. DeFillippi \& Arthur, 1998; Hobday, 2000), the development of project-based relationships and networks (Manning \& Sydow, 2011; Starkey et al., 2000), and the role of project-based learning and capability development (Davies \& Brady, 2004). In sociology, important topics related to projects include the emergence of project-based careers (Jones, 1996), the functions of roles and status positions within and across projects (e.g. Bechky, 2006; Baker \& Faulkner, 1991), and the nurturing of creativity (e.g. Burt, 2004).

One common theme that unites most studies, however, is the so-called 'temporarypermanent' dilemma of project organizing (Sahlin-Anderson \& Soederholm, 2002). This refers to the challenge of maintaining practices, expertise, relationships, and employment beyond the end of any particular project. While the temporary and often unique nature of projects is often seen is a major strength of this organizational form (e.g. Lundin \& Soederholm, 1995), it is also associated with several managerial, social and economic challenges.

\section{The Emerging Industrial Paradigm of Project-based Production}

The literature on project based production provides a mosaic of findings about specific organizational structures and management practices that are found in project-based production, and a compendium of specific solutions that have been devised to address the challenges of such production. Nevertheless, this literature points to the outlines of a more general paradigm of project-based production as an industrial model for advanced economies. In this section, we show how the performance of project-based manufacturing firms depends on integrating three distinct sources of industrial efficiency: (1) the organization of production within and across firms, (2) the relationship between craft-like occupational employment systems within firms and their counterpart external occupational labor markets, and (3) the role of both traditional and "created" regional agglomeration economies.

\section{The Characteristics of Project-based Production}


Project-based production involves products that are "customized" in that they are produced singly or in small batches and are typically part of a product portfolio that has enough variety to generate economies of scope in design, production, and distribution. Over time, project-based production depends heavily on economics of repetition (of certain project practices) and recombination (of resources) (Grabher, 2002b; Davies \& Brady, 2000; Manning \& Sydow, 2011). Project-based products occupy pivotal and often time-sensitive positions in various stages of the product life-cycles of different industries. For example, project-based production is the starting point for prototypes of new products in a wide range of industries, it is the main mode of production in industries with short product life-cycles (as in "quick fashion" apparel and motion pictures or various service industries, such as in the management information sector) and in industries with seasonal production constraints (high-fashion apparel and construction), and it sustains a wide range of mature industries by providing customized equipment for mass production and by supplying replacement parts for older equipment.

A significant amount of project-based production is found, therefore, in sectors where there is considerable new product development that requires the manufacture of prototype products and small batches of samples (e.g. Hobday, 2000; Gann \& Salter, 2000). Examples include new materials and winterization techniques to extend working seasons in construction, greater use of information technologies and quick-response supply chain partnerships for production planning and logistics in the apparel industry (Abernathy et al. 1990), and electronic digitization in the motion picture industry.

The demand for project-based production is often intermittent and unpredictable and the mix of skills required may be hard to determine in advance of production, particularly for prototype products using advanced materials and technologies. As a result, the skill composition and quantities of labor inputs needed may only be approximated during production planning and may need to be adjusted during the early phases of production as the specific needs of each project become apparent. This means that internal employment systems must be flexible enough to combine different skills in different ways and at different levels of scale, and that external labor market mechanisms must be designed to quickly respond to unpredictable demand for skilled and highly adaptable labor.

"Mingled" Occupational Systems 
Urgent production, frequent product changes, use of new materials and technologies, and uncertain product demand require broad workforce skills and adaptable capital equipment in contrast to the dedicated equipment and narrowly-specialized skills of mass production industries. In addition to broad vocational competencies and the know-how to quickly translate general knowledge into a wide variety of specific product applications, workers must also have complex cognitive skills related to trust-building, problem-solving, and team-working, and they often have some discretion over how production assignments are completed (e.g. Bechky, 2003; Haunschild, 2004; Meyerson et al., 1996).

To accommodate these distinctive features of labor demand, internal employment systems in project-based firms are typically stratified horizontally by occupation (Tolbert, 1996). However, occupational boundaries are often permeable or overlapping and groups of workers with different skills often interact with one another in different combinations depending on the needs of each project. This is true not only in project-based firms (Hobday, 2000) or 'adhocracies' (Mintzberg \& McHugh, 1985), but also in matrix organizations where employees typically work on multiple projects under the direction of multiple bosses at the same time (Galbraith, 1971). Because of the fuzziness of occupational boundaries and the variety of ways in which occupations are combined in project-based production, we call these "mingled occupational systems" (MOSs).

By being employed on different projects and by multiple organizations, workers accumulate a wide repertoire of experience, skills, and problem-solving capacities. This enhances their productivity in an environment of rapid and frequent product change (Saxenian, 1996). Interactions among different occupational groups may be simultaneous (as in the filming stage of a movie) or sequential (as in the design, pre-production fabric layout and cutting, and assembly of apparel products), but either way they contribute to the broadening of occupational skills and the facilitation of team interactions. Project-based work also stimulates and relies on the accumulation of social capital both within and across firms (e.g. Baker \& Faulkner, 1991; Grabher, 2004)

MOSs are, in principle, well-suited to accommodate adjustments in the occupational composition of project-based production resulting from changes in materials and technology. They can adapt flexibly to the introduction of new occupations and the shedding of obsolete occupations. When new technologies and new products require new or different skills, and 
especially when these changes cut across multiple occupations, it can be easier for firms to insert these new skills into a MOS-type occupational matrix without disrupting other occupation relationships than it is in vertical employment hierarchies, where skills are often developed sequentially.

However, the advantages of permeable occupational boundaries and flexible occupational composition can become liabilities if crafts and occupations seek to gain economic advantage by asserting jurisdictional control over particular tasks and technologies. For this reason, projectbased production also requires organizational mechanisms for managing occupational conflict both within the MOSs of firms and across external production networks.

Organizational forms of MOSs are varied. They can consist of independent occupations that are brought together to complete a single project as is common in residential and commercial construction and book publishing; of single firms that employ one or more occupations on a relatively permanent basis as is the case with small-scale "artisanal" firms in haute couture apparel and some large-scale video game companies; or they may be multioccupational teams that are brought together to complete a particular project and then shuffled again for the next project, either within a single firms or as a compilation of separate firms that collectively produce a project.

Although broad skills and complex cognitive competencies reduce the costs of direct supervision and monitoring under MOSs, special coordination problems arise in integrating production across different skills and organizational structures and ensuring efficient and timely production. Within firms, there can be coordination by management or self-coordination by teams. When production involves multiple firms, coordination arrangements are often managed by "lead firms" and there are also examples of collective coordination within networks of firms linked by cooperative co-contracting arrangements (see e.g. Manning \& Sydow, 2011).

\section{Occupational Labor Markets}

MOSs draw their labor supplies from occupational labor markets (OLMs) that are similarly structured by craft and occupation. Because project-based production is often time sensitive; often involves new designs, materials, and technologies; and can experience wide fluctuations in labor demand, there is neither the time nor the continuity needed for efficient employer-based training. Instead, firms engaged in project-based production rely on OLMs to ensure that occupational skills are up-to-date and that workers can reach full productivity quickly 
(Saxenian, 1996; Jones, 1996). OLMs must therefore establish close links with occupational education and training institutions and occupational certification procedures (Sydow \& Staber, 2002).

When new technologies require new skills, established OLMs can incorporate new training links and new occupations. Common examples of such formal training institutions include apprenticeship programs for skilled crafts, technical schooling for science and engineering occupations, and arts and communications training for creative occupations. These types of formal occupational preparation are often combined with practical training in apprenticeship trades and through a variety of internship, cooperative education programs, and post-graduate training arrangements in other occupations.

OLMs also contribute to efficiencies in matching jobs and workers. Because much project-based production is for newly-designed and highly-differentiated "one-off" products, labor demand by skill and occupation is inherently volatile and competitive bidding for project contracts can cause further shifting of demand among firms. This volatility in demand raises the inter-firm mobility among workers, increases transactions costs, and disrupts the continuity of returns to human capital. The costs of adapting to these shifts in demand are reduced by OLMs because they are designed to quickly allocate labor as project demand shifts from one firm to another or when multiple skills and occupations must be used in quick succession. Because skills are well-understood within OLMs, either through informal social networks or certification and licensure, the quality of workers' skills is well-known within occupational labor pools (Jones, Hesterly, and Borgatti, 2001). Thus, good matches are easier to determine in advance of hiring, and the transferability of skills allows mismatches to be easily corrected through quits, terminations, and replacement hiring. Examples of such transaction mechanisms are union hiring halls in the construction trades and the networks of senior personnel in film-making that work with entertainment unions to assemble crews who work together on a semi-regular basis and move from project to project.

These efficiencies in education, training, and job matching provided by OLMs are further enhanced by the way in which the costs and benefits of investments in occupational skills are allocated. Because OLM skills are largely transferable among firms, human capital theory tells us that workers, rather than firms, will be responsible for their own skill investments and the workers will receive the returns on their investment. Worker-driven human-capital investment 
relieves employers of training costs and well-functioning job matching arrangements help to ensure that workers will be appropriately compensated for their investments.

\section{The Institutions for Coordinating Project-based Production}

The nexus of craft-like MOSs, OLMs, and occupational training and certification institutions is often identified with networks of small, flexible, and specialized firms such as those highlighted by Piore and Sabel (1984). But in practice it can be found in a much wider range of firm-sizes and multi-firm networks, each with its own mechanisms for achieving quick and efficient project-based production. For large firms, particularly those that also engage in mass production, these mechanisms are mainly concerned with aligning internal business practices with project-base production methods -- the flattening of management hierarchies to be compatible with MOSs (Osterman, 2000, 2006) and the development of technological and organizational protocols for harmonizing quick-response sourcing with traditional procurement arrangements (Abernathy, et al, 1999; Doeringer, Lorenz, and Terkla, 2003).

For smaller firms, however, the coordination of this nexus is often accomplished by external "lead" organizations that serve as project entrepreneurs by regularly initiating projects with various partners (Ferriani et al., 2009; Manning, 2010). Project entrepreneurs often build so-called 'project networks of strategically coordinated and long term relationships with both contractors and service provides that they recruit for particular types of projects (Starkey et al., 2000; Windeler \& Sydow, 2001; Manning, 2005, 2010). Project networks are activated for particular projects, yet they are sustained beyond particular collaborations. They are often highly- coordinated social infrastructures, based within OLMs, because they provide longer-term employment and career opportunities by stringing together a series of short-term projects. For example, in film production, some directors and script writers typically prefer to work for particular producers who serve as project entrepreneurs and project network coordinators. Other examples include general contractors in construction who build up long-term project-based relations within key clients and suppliers (Eccles, 1981); system integrators in complex product and system development (Hobday, 2000); researchers in project-based research networks (Manning, 2010); consulting firms, government agencies in regional and international development fields (Berggren et al., 2001; Manning \& Von Hagen, 2010), and clothing “jobbers" in New York City that purchase materials, organize contracted production, and serve as an intermediary between small producers and large buyers. 
"Collective" organizations -- unions and professional associations, industry associations, and government agencies - may also serve as coordination intermediaries (Rychen and Zimmermann, 2008 and Foster, Manning, and Terkla, 2011). Such coordination responsibilities include skill development, job matching, and certification arrangements, and assistance in organizing research and development activities, developing industry-wide polices, and setting product and employment standards. In the Massachusetts film industry, for example, a specialized government agency was established to promote contacts among out-of-town film producers, a variety of local suppliers of movie-related goods and services, and the local schools and trade unions that represent sources of skilled labor employed in movie production.

\section{Agglomeration Economies and the Economic Geography of Project-based Production}

Project-based production often benefits from several traditional types of local and regional agglomeration economies. For example, MOSs and OLMs facilitate the sharing of occupational labor pools and the value of these shared labor pools is further enhanced by the efficiencies in training and job matching that are often present in OLMs. These pools are further structured by project networks within which project professionals maintain longer-term relationships with other potential key project partners. For example, film directors typically collaborate regularly with the same camera operators and cutters, which reduces transaction costs and allows them to develop certain styles and practices of movie-making in competition with others (Ferriani et al., 2005; Manning, 2005; Manning \& Sydow, 2011).

Project-based production also benefits from access to often regionally bound repositories of knowledge (Grabher, 2004). Occupational labor markets are an excellent vehicle for accumulating and sharing knowledge about products and technologies. Formal occupational knowledge is often kept up-to-date through close contacts among workers and local education and training institutions. Tacit knowledge is kept current as workers gain experience with different project-based products and as their employment rotates among related local firms (Song et al., 2003). Knowledge about the design and manufacture of one-of-a-kind products and about new materials and technologies relevant to prototype production is shared because research institutions and project-based industries often draw workers from the same local labor pools. Because project-based production often involves changes in designs and specifications during 
the production process, proximity to customers is a further type of location externality for facilitating knowledge exchanges between suppliers and their clients.

Firms engaged in project-based production can also collectively augment regional agglomeration externalities. Traditional externalities can be reinforced when firms choose “open" organizational architectures and cultures that encourage knowledge-sharing, rather than those that are "closed" (Saxenian, 1996), and by establishing collaborative sourcing relationships in place of arms-length contracting (Piore and Sable, 1984; Abernathy, et al., 1999, Doeringer, Terkla, and Lorenz, 2003). Other externalities can be created through fundamental changes in market design and the development of new market institutions. Historical examples of such changes are the development of apprenticeship training programs and the facilitation of labor mobility by $19^{\text {th }}$ century craft-based unions (Ulman, 1955, Jacoby, 1991) and the impact of local unions and employer associations on the economic regulation of industries such as apparel and machining (Teper, 1937; Carpenter, 1972; Slichter, Livernash, and Healy, 1960).

\section{The Project-based Production Model: From Concept to Evidence}

In the following section, we provide evidence from two case studies in support of the proposition that the combination of project-based production and project-based regional externalities is a viable paradigm for the future of U.S. manufacturing. The first case, women's wear manufacturing in the New York City garment district, traces a project-based industry from its original roots in craft-based production and traditional agglomeration economies through its growth period as a project-based supplier to mass markets using network governance practices developed by employer association and trade unions, to its recent conversion back to projectbased production coordinated by jobbers and developing new sources of agglomeration economies.

The second case involves an information industry, movie and television production that has long been a model of project-based production with MOSs and OLMs. This industry has evolved from a vertically integrated production model based within large internal labor markets to a disintegrated production model that combines a small group of firms providing financing and overall direction for a complex set of production networks that are responsible for specific projects at production locations that are increasingly dispersed around the world. By closely 
examining the progress of this industry in establishing a production cluster in Massachusetts, we are able to observe the dynamics of an established industry interacting with an "infant" district.

\section{Case Study I}

Women's Wear Manufacturing, Garment District Externalities, and the Product Life-cycle ${ }^{1}$

Apparel, with its seasonal cycle for fashionable products, is a quintessential project-based industry. It is also one of the oldest and most labor intensive industries in the United States and was once one of the largest U.S. industries, employing over 1 million workers as late as 1982. By 2009, however, imports had displaced most domestic production and fewer than 133,000 workers remained in the industry. This dramatic decline in domestic production led to substantial downsizing among the firms that survive and to an increasing concentration of the industry in the two largest U.S. garment districts, New York and Los Angeles (Rice, 2008), both of which are well-endowed with local agglomeration economies that continue to support the industry that remains.

\section{$\underline{\text { Industry Structure }}$}

The industry has always had a competitive structure and been dominated by small and medium-size firms. The average establishment size in 2009 was 17 employees, down from 60 in the early $1980 \mathrm{~s}$, and only $0.8 \%$ of establishments employ 250 or more workers. The morefashionable women's and girl's sector is the largest U.S. product specialization, accounting for $44 \%$ of total industry employment (2009), and it consists almost entirely of project-based

\footnotetext{
${ }^{1}$ Research support for this study was provided by the National Science Foundation under Grant No. 0328635, the Fiscal Policy Institute, the Alfred P. Sloan Foundation, the International Labour Organization, and the Harvard University Center for Textile and Apparel Research. Sarah Crean and Seth Myers made the major contribution to the field research in New York City. I am grateful for comments by my co-authors on this project: Sarah Crean, Bruno Courault, Lynn Oxborrow, Paolo Crestanello, and Daniela Bigarelli, and for the valuable research assistance provide $d$ by Brad Rice and Aparna Garn when they were graduate students at Boston University. I have also benefited from comments by Frederick Abernathy, John T. Dunlop, Janice Hammond, David Weil, May Chen, Edgar Romney, and Mark Levinson as well as those by participants in seminars at the Federal Reserve Bank of Boston, the Garment Industry Development Corporation, MIT, American University, and the International Labour Organization's "Decent Work Forum", as well as from presentations at conferences organized by the Society for Social Economics, Centre for Research in the Arts, Social Sciences and Humanities at Cambridge University, the International Labour Organization, the Industry Studies Association, the Regional Science Association, and the International Working Party on Labour Market Segmentation.
} 
production where designs and styles change seasonally, batches are relatively small, and product life-cycles occur within a season or less.

Apparel production in New York City was originally carried out in fully-integrated artisan shops that acquired fabric and were staffed by skilled tailors who could make patterns, cut fabric, and assemble entire garments. By the 1880s, however, more the standardized and production began to be decentralized to less-skilled sewing contractors. Women's wear manufacturers further extended contracting chains by delegating the organization of production to "jobbers" who acquired fabric and coordinated garment assembly. By the 1920s, the modernday structure of the industry was in place in New York City, with jobbers and their contractors serving much of market for women's wear while "manufacturers" specialized in design, marketing, and other commercial activities.

\section{Occupational Employment Systems and Occupational Labor Markets}

Employment in the apparel industry has always been structured by occupation and the occupational employment systems of apparel firms parallel the sequence of skills used in production. Designers conceive new products, pattern-makers translate the designs into templates to guide the cutting of fabric into the components for garments of different sizes and shapes, and cutters cut the fabric. Garments are then assembled by sewing machine operators, finished by pressers, and then prepared for shipment.

Artisan shops originally hired craft tailors, apprentices, and helpers from a variety of local labor pools, but by the 1880s, foreign-trained immigrants were becoming the primary source of skilled sewing labor for the artisan shops and of semi-skilled sewing workers for the expanding sector of apparel contractors. Sewing eventually became almost entirely a semiskilled industrial occupation, cutting and pattern-making remain separate skilled occupations ${ }^{2}$, and designers became a recognized occupation with its own training programs at the turn of the century. Semi[-skilled production workers constitute almost two-thirds of current employment in cut and sew apparel manufacturing (2010) with sewing occupations accounting for $70 \%$ of all

\footnotetext{
2 The exception is in the few remaining large-scale firms where pattern-making and cutting are largely automated and where electronic and programming skills have replaced traditional craft skills.
} 
production workers followed by cutters (7\%) and pattern makers (4\%). Designers represent about $3 \%$ of total apparel industry employment.

Occupational structures also shaped the structure of union organizing and bargaining. Between the late 1880s and early 1900s, apparel workers began to form unions in response to the greater use of low-wage contractors for sewing work, downward pressure on wages from immigration, and the growth of sweatshop working conditions. The skilled tailors and cutters employed in the cloak and coat sector, New York's largest and most skilled craft at the time, were the driving force behind these early unionization efforts (Levine, 1969, pp, 92-98) and a group of craft-based local unions formed the International Ladies' Garment Workers Union (ILGWU) in 1900. As the industry moved from artisanal to industrial production, however, the ILGWU became primarily a union of sewing machine operators employed by contractors, although skilled cutters retained separate union locals and remained an important source of union power.

The Development of District Externalities in New York City: The Pre-Union Era

Local garment districts have long been characteristic of women's wear production. Short product life cycles and volatile and uncertain consumer demand place a premium on quick and flexible supply chains that can draw upon a variety of agglomeration economies -- large pools of designers and manufacturing labor, ready access to suppliers of fabrics and trims, and proximity to retail and wholesale buyers that can closely monitor the fashion preferences of their customer base. Early in its history, immigration provided New York City with large pools of skilled and unskilled labor that served both craft and industrial modes of production. Its strengths in fashion design gave the district an advantage in setting fashion trends; the size of its apparel manufacturing sector encouraged fabric and other suppliers to locate nearby; and its dominance of national markets attracted national buyers to the district. ${ }^{3}$

\section{$\underline{\text { Pools of Labor }}$}

\footnotetext{
${ }^{3}$ Los Angeles, originally a regional district serving west coast markets, was later able replicate many of these district externalities and began to compete with New York in sportswear and in other somewhat standardized products that it could manufacture at a relatively lower cost. New York City and Los Angeles are now the nation's largest garment districts and together account for $90 \%$ of all U.S. women's wear employment.
} 
The important labor pools for artisan apparel manufacturing were workers with craft skills of cutting and tailoring and the know-how to capture the hang and drape of the fabric anticipated in clothing designs. The major source of skilled labor in the post Civil War period was recent German immigrants as well as second generation Americans who had learned tailoring skills. As the industry grew and diversified in the 1880s and 1900s, it was able to draw upon a large wave of immigrants from Eastern Europe, many of whom had tailoring skills or other apparel industry experience (Levine, 1969, Ch. III). The sheer number of immigrants arriving in New York during that period -- 89,097 between 1882 and 1887, 48,000 a year from 1887 to 1900 , and 107,347 in 1902 - also helped to keep wages for apparel workers low (Pope, 1970, Part II, Ch. I).

As the demand for ready-made women's wear increased, however, manufacturers began to contract production to smaller and more specialized firms that were being opened largely by immigrant entrepreneurs and staffed by semi-skilled immigrant workers (Levine, 1969, Ch. III; Waldinger, 1986). Low overhead, relatively inexpensive labor, and the willingness of immigrants to work hard and accept intermittent jobs allowed these small contracting shops to successfully compete with the larger and more-established manufacturers that employed skilled labor and their share of output continued to grow throughout the late $19^{\text {th }}$ and early $20^{\text {th }}$ centuries (Pope, 1970, pp. 62-65).

\section{$\underline{\text { Proximity to Suppliers }}$}

At the turn of the century, New York's emerging apparel manufacturing drew upon suppliers that had been serving skilled tailors, seamstresses, and small artisan tailoring shops. With the growth of demand for fashionable women's wear, the industry began its relocation to a new and diversified fashion cluster in a thirty-five block area in mid-town Manhattan that included manufacturers, showrooms, and contractors. This new manufacturing and sales district also attracted a variety of specialized suppliers - fabric and clothing wholesalers, button shops, pattern-makers, cutting shops, sample makers, embroiderers, dyeing and finishing firms, and equipment mechanics - that had the commercial skills needed to supply the increasing variety products required by highly-differentiated women's wear fashion production.

\section{Proximity to Buyers}


New York was the first garment district to serve a national market. Larger New York City manufacturers initially hired salesmen to visit buyers while smaller manufacturers sold through wholesalers who served small retailers. As national markets and large retailers grew in importance, and as styles, fabrics, and grades of clothing began to proliferate, New York City manufacturers and jobbers began to operate showrooms for buyers who were travelling to New York in advance of each season to view the full range of products available in the district. By 1919, New York City was an established location for buyers and the need for travelling salesmen was virtually eliminated (Levine, 1969, pp. 413-415).

\section{Pools of Fashion and Design Knowledge}

New York has been at the forefront of fashion and product innovation since the early $19^{\text {th }}$ century when its seamstresses and tailors benefited from the flow of ideas about fashion trends in Europe brought back by affluent tourists or copied from clothing imported from France and England (Green, 1997, p. 112-114). New York's first fashion specialization in tailored women's wear products in the 1880s, but its demand for design ideas expanded rapidly as the district added specializations in shirtwaists in the early 1900s and then dresses, which became New York's largest specialization in the 1920s with 125,000 different dress styles being produced in New York by 1939 (Hochman, 1941).

New York began to develop its own sources of design in the early twentieth century. New York-based Vogue Magazine switched from featuring articles on cultural topics of broad interest to a focus on fashion and design beginning in 1909; the Women's Wear Daily trade newspaper was founded in 1910; and district-wide fashion shows became an important public venue for showcasing fashion ideas beginning in 1943.

New York began to develop a training infrastructure for producing its own fashion designers when The New York School of Art (which later became the Parsons School of Art and Design) launched a specialized fashion design program in 1904 to serve the market for theatrical costumes. By the boom period of the New York City garment industry in the 1920s, the Parsons School had become a general school for fashion and design with links to the European fashion industry and a pioneering fashion program in Paris. The 1920s was also the beginning of a long period of intense product differentiation (National Retail Dry Goods Association, 1936), which 
further increased the demand for trained designers and led to the founding of a second fashion design school, the Fashion Institute of Technology, in 1936.

\section{The Union Era: Collective Bargaining and "Created" District Advantage}

Increased immigration and the growth of immigrant contractors in the late 19th century led to intensely-competitive labor and product markets, excess production capacity, falling wages, and the growth of sweatshop conditions (Levine, 1969, pp. 403-407, 409; Teper, 1937, pp. 13-14). Wages of factory-based sewing machine operators in 1906, for example, were $49 \%$ higher in Chicago than in New York, 34\% higher in Boston, and 23\% higher in Baltimore, with only Philadelphia coming close to New York's wage level (Segal, 1960, p. 94).

Continued immigration intensified competition, low wages, growing economies of scale, and strong agglomeration economies contributed to industry growth by holding down production costs and allowed the New York City garment industry to gain a $64.5 \%$ share of national apparel markets by 1899 (Levine, 1969). But falling wages, volatile employment, and poor working conditions (Levine, 1969, pp. 168-173) also led to spontaneous strikes and labor violence. Labor conflict became a negative externality for the entire district by encouraging buyers and suppliers to shift orders to other districts with less labor unrest.

The inefficiencies of strikes became an even more serious concern in the $1880 \mathrm{~s}$ as garment workers began to form trade unions. Skilled tailors and cutters employed in the cloak and coat sector were the driving force behind these early unionization efforts (Levine, 1969, pp, 92-98) because of their numerical strength and hard-to-replace skills.

By the 1890s, New York garment unions were becoming larger and more numerous, and their bargaining tactics became more militant with demonstrations, marches and mass picketing. In 1900, New York's largest craft workers' union, the United Brotherhood of Cloak Makers' Union No. 1 of New York and Vicinity, convened a national convention of "all workers in the trade" to establish a nation-wide, craft-based union for skilled workers in the women's clothing industry that would be headquartered in New York City (Levine, 1969, pp. 102-103), and the craft-oriented American Federation of labor issued a charter to the International Ladies' Garment Workers' Union (ILGWU) shortly thereafter (Levine, 1969, p. 103). 
Employer opposition to unions intensified as union militancy increased. Workers who joined unions were discharged, lockouts were used more frequently when union workers went on strike, and larger strikes and demonstrations often led to arrests and sometimes prison terms for strikers.

The union strategy for overcoming employer opposition was to rely on even larger "general" strikes to force employers to the bargaining table. The 1909 "Uprising of the 20,000" (in support of shirtwaist and dress workers) and the 1910 "Great Revolt" (involving about 60,000 strikers in support of cloak and suit workers), along with pressure from civic leaders and government officials, forced employers to recognize the ILGWU unions and to turn to their industry associations to represent them in negotiating collective bargaining agreements.

\section{$\underline{\text { Collective Bargaining as a Positive District Externality }}$}

The early labor contracts contained traditional labor benefits of wage increases, improved working conditions, and greater employment security for union members. However, the 1910 cloak and coat agreement (known as the "Protocol of Peace") also included provisions that affected market structure and district efficiency. This contract provided for arbitration procedures to prevent the disruption of production by strikes over both worker grievances and future contract negotiations, and it stabilized the employment of craft workers in inside shops by limiting the amount of contracted production (Levine, 1969, pp. 194, 196-98; Carpenter, 1972, Ch. 2). This combination of economic benefits for workers, limitations on competition from contactors, and the efficiencies of reducing strikes and stabilizing employment among manufacturers was subsequently replicated in agreements covering New York City's other major product specializations in 1913, and the scope of district-wide market regulation through collective bargaining was substantially broadened in subsequent contract negotiations.

As the New York City industry moved towards a more industrial and less craft-based production model, the structure and content of union regulation adapted to these changes. When jobbers replaced manufacturers as the key contracting organizations in the 1920s, they became the focal point for collective bargaining, particularly in the dress sector where styles were proliferating as mass markets expanded during the 1920s. 
During this period, the unions \envisioned a major restructuring of the industry to reduce excess capacity, stabilize employment, and "remove" wages and working conditions from competition (Levine, 1969, pp. 422-424). Limits were placed on the number of contractors each jobber could employ in order to control excess capacity; contracting relationships were made more permanent by designating the specific contractors assigned to each jobber; contract prices were required to cover fixed as well as variable costs in order to reduce turnover among contractors; jobbers were obliged to share work equitably among their contractors; and the peaceful settlement of labor disputes was strengthened by establishing full-time paid positions for the chairmen of arbitration procedures. To reduce competition from outside the district, equal prices were to be paid for comparable contracted work regardless of whether it was performed by New York contractors or elsewhere, penalties were levied against runaway shops leaving the district, and the union had a contractual obligation to organize competing employers outside the New York City district. These regulations governing competition remained part of the union's compact with employers in New York City for the balance of the century (Teper, 1937, pp. 1920, 28; Carpenter, 1972, pp. 115-138, 326-366, 488-489).

While monopolistic restraints on trade are normally considered to be inefficient, many of these practices had positive efficiency consequences for the district when compared with the inefficiencies of cut-throat competition and strikes. Compulsory arbitration, for example, helped to reduce the disruptions from labor strife, controlling excess capacity improved resource allocation, price-fixing reduced uncertainty, and minimum size-of-firm requirements helped to eliminate marginal firms and to ensure that surviving firms could achieve a minimum efficient scale of production. In addition, the ILGWU directly contributed to district efficiency by encouraging mechanization and the adoption of efficient work practices by providing training and industrial engineering services to help unionized firms improve their production systems and work organization (Disher, 1947).

Efficiency effects also flowed from the pairing of jobbers with specific contractors, and from the preferences granted to these dedicated contractors in the awarding of contracts and in the equitable sharing of work at uniform contract prices. Continuing and exclusive relationships between jobbers and contractors provided new opportunities for investments in relationshipspecific knowledge that improved both the productivity of contractors and the efficiency of 
contracting relationships. Jobbers could learn the strengths and weaknesses of their dedicated contractors and train them to be more efficient, contractors could learn about their jobbers' products and expected quality standards, and stronger channels of communication between jobbers and contractors could help jobbers to secure orders and improve profits. These stable contracting relationships applied primarily to the "core" group of experienced contractors in New York City who worked mostly for one jobber and had a regular flow of orders, in contrast to the remaining group of "peripheral" contractors who had highly-competitive, arms-length market relationships with multiple jobbers.

The ILGWU was reported to represent over $90 \%$ of women's wear employment in the district during this period (Levine, 1969, p. 424) and was the major enforcer of these agreements by using strikes and boycotts against firms that violated their contractual obligations. By the end of the 1920s, a transition from cut-throat competition to market governance through collective bargaining was well underway and New York employers had come to realize that the regulation of product competition through collective bargaining generated both monopoly rents and efficiency gains that could be profitably shared with their unions.

While collective bargaining was never able to fully control market entry, it presumably slowed the outflow of New York City production to other districts and helped to preserve the agglomeration economies of the district. But there were also more lasting efficiency consequences that flowed from the creation of more permanent relationships between jobbers and their core contractors. Both parties were better able to invest in relationship-specific human capital and the obligation of jobbers to share work fairly among contractors and at a common price led to the development of embedded obligations of reciprocity between jobbers and contractors.

The Product Cycle and the Decline of the New York Garment District

Industrial production emerged as the norm in the district during the 1920s, based on a three-tier contracting chain of specialized manufacturers, jobbers, and contractors coupled with union regulation of labor and product markets. The district developed a manufacturing model that combined the flexibility of small scale craft production with the efficiencies of specialized supply chains and of scale economies from the division of labor. Jobbers specialized in securing materials, organizing production by contractors, and marketing clothing to retailers. Contractors 
specialized in fast, flexible, and low cost sewing and final assembly. The presence of the jobbercontractor system allowed larger manufacturers to abandon production and to concentrate instead on building their scope economies of design, brand development, and marketing, while using jobbers and contractors to capture scale economies of manufacturing and provide quick and flexible supplies of many different products. Small manufacturers, with the flexibility to switch quickly from one product to another, served high-end market niches by designing and producing smaller orders of high-quality products at relatively quick speeds.

The ILGWU in New York went through a corresponding change during this period. Its bargaining strength was originally derived from skilled workers with strong ethnic and religious ties that fostered union solidarity. As the industry came to rely more heavily on mass production methods, skilled craft workers continued to represent a hard-to-replace skill and often retained their own union locals, but the union membership was shifting from manufacturers to contractors and from skilled to less-skilled jobs and the ILGWU became a predominately industrial union after the 1920s.

The 1920s also marked the peak of New York City's dominance of apparel production. While it continued to grow thereafter, its market share began to decline. The halting of immigration weakened the district's labor cost advantage and strengthened the trend for production to decentralize towards districts in the south and west where land and labor costs were lower, fabric could be sourced more cheaply from textile suppliers that had relocated to the South, and unions became weaker as the district's market share fell. Fashion preferences were also shifting away from New York City's traditional specializations in dresses and tailored women's wear towards more casual blouses, skirts, and trousers. Many of these more-casual products could be produced more efficiently in large factories using large-scale mass production methods rather than by the smaller-scale and more flexible production networks prevalent in New York. The decentralization of production and the growing number of large manufacturers also made it easier for suppliers to sell directly to retailers instead of going through jobbers and buyers in New York City.

The Great Depression of the 1930s further challenged the union-regulated system of market protection and efficiency promotion in New York City as employers sought to cut costs and prices in the face of sharply reduced demand for clothing and as union strength was eroded 
by membership losses. The passage in 1933 of the National Industrial Recovery Act (NRA) gave union regulation a brief respite by incorporating much of the regulatory structure of the district's collective bargaining agreements into the NRA industry codes (Carpenter, 1972, Chs. 16-18). However, with the demise of the NRA in 1935, the apparel industry in New York largely returned to the earlier system of private regulation through collective bargaining. By the end of World War II, New York's market share had fallen to 54\%.

While the full extent of the import penetration that would occur later in the century was not anticipated in the 1950s, New York was clearly experiencing a transition from a high-growth to a mature and declining district (Helfgott, 1959, pp. 68-93; Vernon, 1979). It had been losing men's wear production and less fashionable, and more standardized women's wear products since the 1920s and neither its strong district externalities nor the regulation of market entry through collective bargaining were able to stem the shift of mass production to regions in the south and west where wages were lower, unions weaker, and scale economies were more readily available.

The changing composition of output was also redefining New York's district advantages. New York continued to be successful in the design and development of new products and in small batch manufacturing. A large-study of the district in the mid-1950s concluded that New York was increasingly a district of smaller firms producing the most rapidly-changing apparel products that had the least stable and predictable demand (Vernon, 1960, Ch. 5). Its emerging district advantages were in producing more-fashionable products that required somewhat different agglomeration economies from those that contributed to large-scale production - labor pools of relatively skilled occupations (fashion design, pattern-making, broadly-skilled sewing machine operators), proximity to suppliers of relatively small quantities of diverse fabrics and trims, and easy access to higher-end retailers and branded manufactures. In this sense, the district was already embarking on a return to its smaller-scale craft roots.

In the intervening years since the mid-1950s, production of more-standardized and more casual clothing continued to be transferred to lower-cost production centers in the United Sates 
and then to offshore suppliers in the late 1960s. ${ }^{4}$ As employment and output fell, New York City retained design, supply chain management, and marketing activities. The apparel manufacturing sector continued to serve smaller and more unpredictable market niches, although these niche markets included lower-end as well as fashion products. Skilled labor pools remained important as the New York district downsized, but mostly in pre-production activities (such as patternmaking and grading), supply chain logistics, buying and selling occupations, and in sewing operations where workers needed to be broadly-skilled in order to perform a wider range of high quality tasks on each garment and to be able to switch quickly from one product to another. Proximity to suppliers and buyers continued to be important, and the pool of suppliers learned to quickly provide a broad range of fabrics and trims in relatively small quantities.

Declining output weakened the regulatory power of collective bargaining as union membership fell. The ILGWU represented less than half the apparel employees in the district by the 1980s and only 30-40\% in the 1990s (derived from Levitan, 1998, quoted in Milkman, p.88).

\section{A Disappearing District in New York During the Second Non-Union Era?}

By 2000, the New York City industry had been downsizing for over four decades and the decline showed no signs of slowing. Employment in women's wear (Manufacturers, NAICS 31523 and Contractors, NAICS 315212) in New York City declined by 68.9\% between 2000 and 2009 (see Table 1), with the greatest decline was among contractors (71.9\%). Nevertheless, New York continues to employ a relatively large number of workers in women's wear $(13,532$ in 2009).

New York also lost 58.2\% of its women's wear manufacturers and 57.2\% of its women's wear contractors -- a slower rate of decline than in employment during this period. By 2009, it had only 355 manufacturers and 680 contractors. The average size of manufacturers in New York remained relatively stable at between 17 and 18 employees throughout the decade, but contractors fell in size from an average of 16 employees in 2000 to 11 employees by $2009 .^{5}$

\footnotetext{
${ }^{4}$ Offshore sourcing was accelerated by a series of trade liberalization policies -- the Caribbean Basin Initiative (1985), NAFTA (1994), and the more general reductions in apparel tariffs and quotas from 1994 to 2005 under the Uruguay Round of GATT negotiations.

${ }^{5} \mathrm{~A}$ third way of measuring decline is through data on output. While data on women's wear output are not available at the district level, there is state-level data on value-added for the cut-and-sew apparel sector (NAICS
} 
3152). Because New York City account for a large fraction of apparel production in New York State, trends in statewide data provide a reasonable approximation of those at the district level. During the decade of the 2000s, New York's cut and sew apparel industry experienced a fall of $76.2 \%$ in its real value-added. The magnitudes of this statewide declines in real value-added is somewhat larger than the corresponding change in employment. 


\begin{tabular}{|c|c|c|c|c|c|c|c|c|c|c|}
\hline & & $\begin{array}{l}\text { Table } 1 \\
\text { New York City's } \\
\text { Women's Wear Industry } \\
\text { (2000-2006) } \\
\text { WOMENS \& GIRLS CUT \& SEw } \\
\text { MANUFACTURERS in New York City }\end{array}$ & & & & & NAICS & 31523 & & \\
\hline Year & 2000 & 2001 & 2002 & 2003 & 2004 & 2005 & 2006 & 2007 & 2008 & 2009 \\
\hline Employment & 16,791 & 14,532 & 12,557 & 10,900 & 10,573 & 7,928 & 8,496 & 6,783 & 6,388 & 6,018 \\
\hline Number of Firms & 945 & 806 & 720 & 594 & 539 & 343 & 420 & 322 & 316 & 355 \\
\hline Establishment Size & 17.8 & 18.0 & 17.4 & 18.4 & 19.6 & 23.1 & 20.2 & 21.1 & 20.2 & 17.0 \\
\hline \multirow[t]{2}{*}{ Average Earnings } & $\$ 47,873$ & $\$ 53,560$ & $\$ 58,722$ & $\$ 64,766$ & $\$ 70,859$ & $\$ 83,400$ & $\$ 76,712$ & $\$ 94,375$ & $\$ 94,458$ & $\$ 88,769$ \\
\hline & & $\begin{array}{l}\text { WOMEN \& GIRLS CUT \& SEW } \\
\text { CONTRACTORS in New York City }\end{array}$ & & & & & & NAICS & 315212 & \\
\hline Year & 2000 & 2001 & 2002 & 2003 & 2004 & 2005 & 2006 & 2007 & 2008 & 2009 \\
\hline Employment & 26,702 & 21,094 & 9,332 & 14,482 & 14,440 & 12,456 & 11,302 & 6,208 & 9,478 & 7,514 \\
\hline Number of Firms & 1,588 & 1,447 & 668 & 1,133 & 1,005 & 970 & 856 & 456 & 747 & 680 \\
\hline Establishment Size & 16.8 & 14.6 & 14.0 & 12.8 & 14.4 & 12.8 & 13.2 & 13.6 & 12.7 & 11.1 \\
\hline Average Earnings & $\$ 14,391$ & $\$ 14,917$ & $\$ 18,512$ & $\$ 15,912$ & $\$ 16,548$ & $\$ 18,968$ & $\$ 20,651$ & $\$ 28,293$ & $\$ 24,814$ & $\$ 25,031$ \\
\hline Year & 2000 & 2001 & 2002 & 2003 & 2004 & 2005 & 2006 & 2007 & 2008 & 2009 \\
\hline Total Employment & 43,493 & 35,626 & 21,889 & 25,382 & 25,013 & 20,384 & 19,798 & 12,991 & 15,866 & 13,532 \\
\hline Total Firms & 2,533 & 2,253 & 1,388 & 1,727 & 1,544 & 1,313 & 1,276 & 778 & 1,063 & 1,035 \\
\hline
\end{tabular}




\section{Market Re-design and "Created" Agglomeration Economies in New York ${ }^{6}$}

As the international product cycle continued to take its toll on New York City's garment industry, the district began to replace its weakened system of union regulation with a non-union regime designed and operated by surviving jobbers who had been part of the earlier union regulation system. These jobbers opted to retain the strong ties with their core contractors that had been established under union regulation by continuing to give them preference in the sharing of orders, and by developing new and more powerful efficiency incentives for contractor performance.

"Locked-in" contracting relationships meant that jobbers and contractors could continue relationship-specific investments in skills and knowledge without fear of losing the returns on these investments if their contractors worked for competing jobbers. Preferential contracting has helped core contractors to survive as demand declined and these contractors have reciprocated by helping their jobbers to win more orders by maintaining quality standards, adhering to tight delivery schedules, and advising jobbers on how manufacturing costs could be reduced. ${ }^{7}$

\section{Excess Capacity and the Efficiency Contracting Model}

Jobbers, however, abandoned their previous practice of adjusting the number of core contractors so as to keep contractors operating at close to full capacity and instead are using order-sharing to keep as many as possible of their core contractors in business. During our interviews in 2003, jobbers frequently spoke about declining business, their obligation to support their core contractors, and their reluctance to drop contractors from this core group. The resulting

\footnotetext{
${ }^{6}$ This section is based on field research in New York City that was conducted in 2003 by Sarah Crean and Seth Myers under the auspices of the Fiscal Policy Institute, with Peter Doeringer participating in some of the interviews and data analysis. Survey data was collected during a series of in-depth interviews with a representative sample of 34 apparel firms in the New York City garment district in 2003. The project also had access to a counterpart survey in 2003 of 116 unionized apparel contractors in New York City, provided by the UNITE trade union. These surveys were supplemented by additional interviews with UNITE officials, large branded manufacturers, retailers, and industry associations. Doeringer conducted more recent data analysis and follow-up discussions with industry experts.

7 These embedded obligations led to a distinction between the "core" and "peripheral" contractors in terms of productivity, earnings, and continuity of work, as noted by Uzzi $(1996,1997)$ and Palpacuer $(1997)$ in their earlier studies of the New York City garment district in the 1980s and 1990s. Uzzi also documented the higher survival rates of core contractors relative to those in the peripheral sector of the New York district.
} 
excess capacity from retaining more contractors than were needed as demand declined was evident from the idle machinery and empty production lines we observed when visiting manufacturers and contractors, Our survey data also documented an average capacity utilization rate of $37 \%$, far less than the national average utilization rates for women's wear contractors of $66 \%$ at that time. ${ }^{8}$

The contractors we interviewed recognized that this excess contracting capacity put them at risk of having to close if the industry continued to decline and they appeared to be making "end-game" price and cost responses. ${ }^{9}$ They lowered prices, absorbed the costs of changes in orders, accepted faster production schedules, and were "on call" day and night to consult (often face to face) with their jobbers in hopes that they and their jobbers could remain in business for a little longer. Contractors also transmitted these cost-control and productivity pressures to their employees by asking them to accept lower wages, production speedups, and sometimes deteriorating working conditions in exchange for a commitment to sharing available work so as to retain as many of their employees as possible.

The creation of excess capacity to lower contracting costs and raise contractor effort resembles the practice among manufacturers in New York during the earlier non-union era in the 1890s and 1900s to support a large periphery of underutilized contractors to hold prices down. ${ }^{10}$ However, the excess capacity being generated more recently by jobbers is targeted at core, rather

\footnotetext{
${ }^{8}$ Capacity utilization in 2003 was also substantially below capacity utilization rates reported among apparel contractors in Manhattan during the Depression (Teper, p. 20).

${ }^{9}$ The effects of falling demand and excess capacity are well-described by simple economic theories of the firm. Fewer orders from jobbers and rising excess capacity caused contractors to reduce prices and raise productivity to avoid reaching their shut-down point where minimum average variable costs were no longer covered by marginal revenues. See, for example, Waldman and Jensen (2001) for a discussion of "shut-down" conduct under perfect and monopolistic competition (pp. 30-33, 44-46).

${ }^{10} \mathrm{New}$ York manufacturers in the 1890 s and 1900 s deliberately fostered excess capacity by allocating small amounts of their orders to a large cadre of contractors based only on price and without any preferential contracting arrangements, and then relying on "cut-throat" competition to keep contract prices low. What distinguishes the modern version of efficiency contracting from this earlier use of excess capacity is that current excess capacity incentives are combined with paternalistic attitudes among jobbers and a sense of reciprocal obligations between jobbers and "core" contractors. Paternalism and reciprocity with core contractors reinforce the incentives of excess capacity and sustain the benefits of relationship-specific investments in human and social capital that are possible when there is continuity in contracting relationships.
} 
than peripheral contractors, and is incorporated into the framework of reciprocal obligations established under union regulation. Jobbers allocate orders among core contractors in a paternalistic way that seems to place contractor survival ahead of jobbers' concern for profits and for the standard efficiencies associated with having a smaller number of contractors working at full capacity. Contractors, in turn, are even more willing to reciprocate by increasing their obligations to help their jobbers accommodating their cost and production needs. Because there are tradeoffs between the efficiencies of operating at full capacity and the effort incentives provided by excess capacity, jobbers can maximize the profits from such "efficiency contracting" by choosing the optimal rate of excess capacity that balances the marginal efficiency losses of underutilized contractor capacity against the marginal efficiency gains from lower prices and higher contractor effort.

\section{Measuring the Impact of Efficiency Contracting}

The introduction of efficiency contracting practices did not slow the decline of the New York City garment district as measured by employment, but employment change is not the appropriate impact measure for practices that were intended to raise the productivity of core jobbers and contractors in the district. Unfortunately, district-level measures of productivity are not available, but data on real value-added per employee can be calculated for the aggregate cut and sew apparel industry (NAICS 3152) at the state level and is a reasonable indicator or productivity change at the district level. ${ }^{11}$ By this measure, labor productivity in New York City rose by $65 \%$ between 2000 and 2006 when efficiency contracting practices were being implemented, but then declined throughout the balance of the decade. By 2009, however, it still remained $12 \%$ above its level in 2000.

While these appear to be large improvements in productivity, they are difficult to interpret in isolation because of the effects of continuing declines in output and employment and the lack of controls for other influences on labor productivity. One approach for sharpening the

\footnotetext{
${ }^{11}$ Because Los Angeles County accounted for $92 \%$ of all shipments of cut and sew apparel manufacturing in California in 2009 and the corresponding share of New York State shipments accounted for by New York City was $88 \%$, statewide data provide a reasonable approximation of those at the district level.
} 
interpretation is to make a quasi-experimental comparison between New York City and its most similar district, Los Angeles, using state-level.

Los Angeles was a late-developing "satellite" district that began to draw production away from New York in the 1920s when it developed a sportswear design capacity. The Los Angeles district built its advantages around the same traditional agglomeration economies as New York and, by the 1920s, had adopted a similar industrial production model using semi-skilled rather than craft labor. While New York gradually lost employment, Los Angeles overtook New York as the largest U.S. apparel district in the late 1980s and continued to grow through the late 1990s. Although Los Angeles is now declining, it lost jobs at a slower rate than New York City during the 2000 s (47.3\% compared to $68.9 \%$ in New York) and its women's wear employment is about three times larger than New York's.

There are other differences between the two districts besides size and growth -- its manufacturers operate on a larger scale (averaging 44 employees compared to 18 in New York City) and it is known for its sportswear and casual clothing whereas New York is known for its dresses and tailored women's wear. However, these differences should not be overstated because four of the five largest specializations in both districts overlap and contractors in both districts are of roughly similar size (12.5 compared to 11 in New York).

What is most important for this benchmarking of productivity change, is the difference in the production regimes in the two districts. Unlike New York City, Los Angeles deliberately rejected union regulation as a source of efficiency in favor of promoting intensely-competitive product and labor markets. Apart from a handful of craft unions in the early decades of the $20^{\text {th }}$ century and some organizing by the ILGWU in the 1930s and during World War II, the apparel employers in the Los Angeles district have successfully resisted unions. Similarly, Los Angeles has a long history ignoring minimum wages, overtime regulations, and health and safety standards in a climate of relatively lax enforcement of labor standards (Light, 1988, 2006; Bonacich and Appelbaum, 2002; Doeringer, 2012), and its loosely-regulated low-wage labor market benefited from an unusually large wave of immigrants during the 1980s that drove down apparel industry wages (Light, 2006, Ch. 4). 
During the 2000s when New York was implementing its new system of jobber regulation and efficiency contracting, Los Angeles continued to follow its traditional practice of relying on arms-length market competition between manufacturers and contractors. Apparel manufacturers in the Los Angeles district continued to take advantage of the increased immigration and weak enforcement of labor standards to reduce labor costs, and they continued to rely on the incentives of competition in declining markets to keep contracting prices low. As a result, benchmarking the trends in New York's labor productivity during the 2000s against those in Los Angeles also represent a comparison of competing modes of garment district design.

Comparing the trends in the real value-added per employee for New York and California reveal both striking similarities and remarkable differences (Chart 1). New York and California experienced similar overall trends in productivity - rising through 2006 and falling thereafter -suggesting that the same broad economic forces were affecting productivity in both districts. ${ }^{12}$ However, New York had a small productivity advantage (3.3\%) over California at the beginning of the decade, its lead increased to a high of $26.4 \%$ in 2008 , and it retained a $3 \%$ productivity advantage over California at the end of the decade. Over the entire period, labor productivity in New York State averaged $13.3 \%$ above California's. This productivity advantage is consistent with the objectives of the efficiency contracting system being adopted in New York City during this period when compared with productivity under Los Angeles' highly-competitive market regime.

\footnotetext{
12 The most likely explanation for this fall in labor productivity is a combination of increased excess capacity caused by the steep declines in output after 2006 and the loss of scale and scope economies as the number of larger manufacturers fell in both districts.
} 


\section{Chart 1}

\section{Real Value Added Per Employee Cut and Sew Manufacturers and Contractors (NAICS 3152)}

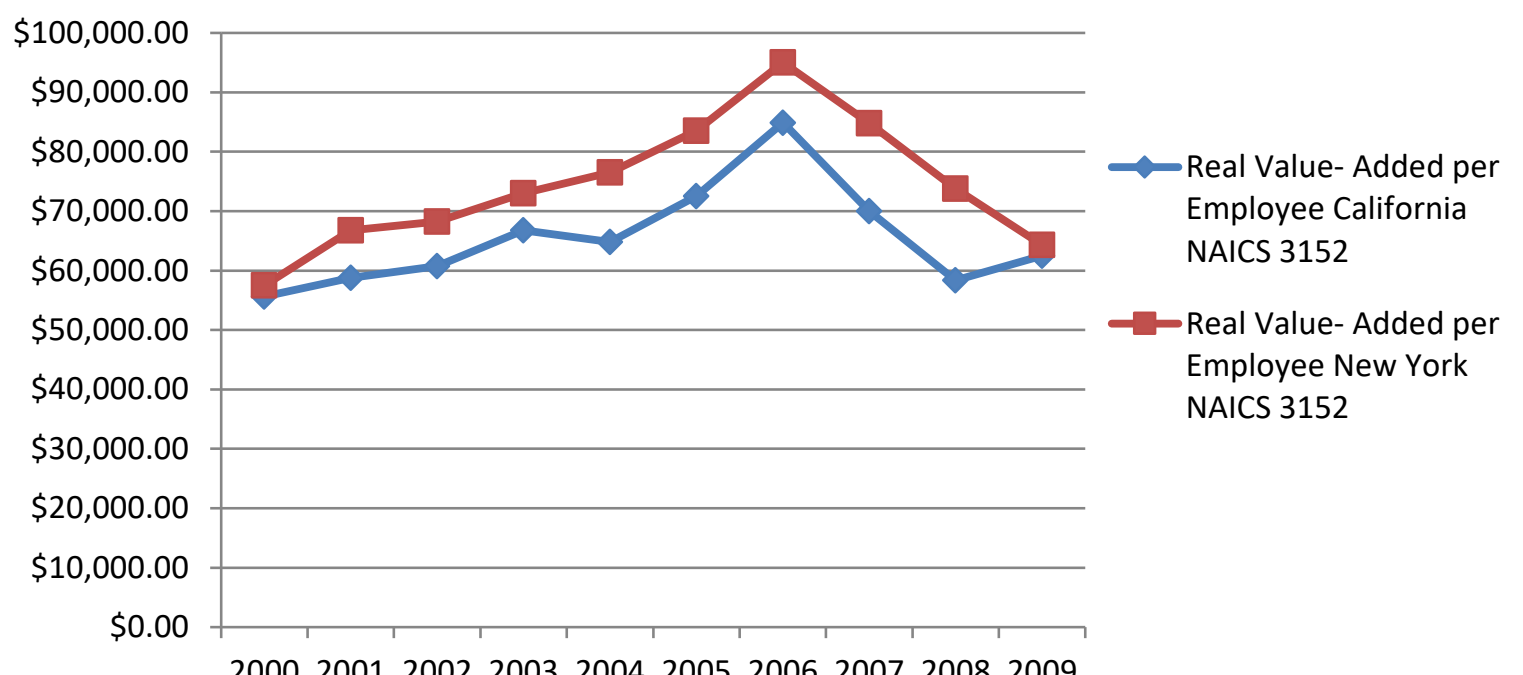

2000200120022003200420052006200720082009

\section{$\underline{\text { Some Caveats }}$}

The correlation between differences in productivity growth and differences in district regimes does not, of course, prove causality. It could be argued that some traditional agglomeration economy or other unobserved district advantage might explain the relatively stronger growth in labor productivity in New York relative to California.

For example, one possibility is that falling wages in Los Angeles relative to New York caused employment to fall more slowly and resulted in a gap in marginal labor productivity between the two districts. Los Angeles did gain a wage advantage over New York as a result of a spike in low-skilled immigration in the 1980s and 1990s that lowered wages in apparel as recent immigrants displaced more established workers in the apparel industry (Light, 2006) ${ }^{13}$ and these

\footnotetext{
${ }^{13}$ During the 1980s, more than 1.5 million new immigrants came to Los Angeles, $60 \%$ more than the roughly 950,000 new immigrants that arrived in New York City (ibid.). Light (2006, Ch. 4) summarizes the literature showing the absolute and relative declines in the wages of low-skilled workers and the growth in informal employment that accompanied this increased immigrant labor supply in the 1980s.
} 
wage advantages continued in the 2000s, at least according to surveys of wages in sewing occupations (U.S. Department of Labor, May 2011). In addition, Los Angeles may have gained cost advantages from more widespread violations of wage and hour regulations than occur in New York (Weil and Mallo, 2007). But there is offsetting evidence from the Quarterly Census of Employment and Wages (QCEW) that average earnings for all employees in the Los Angeles contractor sector were somewhat above those in New York during most of this period.

The presence of larger-scale manufacturers and contractors could confer economies of scale and scope on the Los Angeles district that are not available in New York, but this argument favors higher productivity in Los Angeles unless the smaller scale of establishments in New York could offer offsetting advantages of greater speed and flexibility in serving smaller markets for highly-differentiated and higher-priced fashion products.

Another plausible explanation is that there are differences in specialization, with New York increasingly producing more fashionable products with higher value-added while Los Angeles produces increasing amounts of lower value-added products. This explanation is partially supported by employment data on the product specializations of manufacturers showing that New York specializes more heavily in women's tailored suits and coats while Los Angeles specializes more in women's blouses and shirts. But the largest specializations in both districts overlap and there is no a priori reason to believe that value-added per worker is higher for fashion products that require more time to produce than for more casual apparel products that have lower labor content per garment.

There is an equally ambiguous picture with respect to traditional agglomeration economies. Occupational labor pools are featured prominently in this agglomeration literature as both as a source of skill and as a conduit for information about products and supply chain operations. Clearly Los Angeles has the larger aggregate labor pools for both manufacturers and contractors, and this advantage is also evident in more-detailed data for apparel production occupations (U.S. Department of Labor, May 2011, various occupations). The labor pool in Los Angeles for sewing machine operators is 2.1 times larger than in New York, 3.7 times larger for cutters, and $68 \%$ larger for patternmakers. These labor pool advantages, however, are reversed in the case of fashion designers where New York had 6,790 fashion designers (2010) or about 2.6 times as many as the 2,640 designers in Los Angeles. 
Proximity to suppliers and the size of supplier pools are also important externalities important for both districts. Using employment as an indicator of size, for example, shows that Los Angeles has a 61\% employment advantage (2009) over New York in suppliers of manufacturing inputs such as fabric, trimmings, zippers, and needles, while New York has a (narrowing) 9\% employment advantage in the wholesale distribution of women's wear.

However, in an industry like apparel where product differentiation is important, the appropriate measure of "size" may be the number and variety of firms within supply chains rather than the scale of the sector. By this measure, New York had a 4\% advantage over Los Angeles in the number of suppliers of fabric and other inputs, as well as a $5 \%$ advantage in the number of women's wear wholesalers.

After examining a number of alternative explanations for New York's productivity advantage over Los Angeles, the admittedly imprecise data point to New York and Los Angeles having somewhat different, but not necessarily unequal, profiles of district advantages. New York gained a modest advantage in labor productivity over Los Angeles during the 2000s while Los Angeles retained a greater share of employment and output, yet neither district reduced costs sufficiently to stem the net outflow of production, and the productivity gains achieved in both districts by the 2006 were largely erased by the end of the decade. Although additional research evidence would be useful, efficiency contracting remains the leading hypothesis for explaining productivity differences between New York City and Los Angeles.

\section{$\underline{\text { Will Market Re-design Succeed in New York City? }}$}

Some additional evidence on whether efficiency contracting is likely to improve the survival prospects of the New York City garment district relative to the Los Angeles district comes from major assessments of the strengths and weaknesses of the two districts conducted by local industry experts (The Municipal Arts Society of New York, 2011; Community Redevelopment Agency of the City of Los Angeles, 2011; California Fashion Association, 2011). These studies have mapped out optimistic scenarios for the future of their districts and comparing their development strategies provides additional insights for understanding the interactions between the women's wear apparel industry and its district advantages. 


\section{$\underline{\text { Higher-Road and Lower-Road District Development }}$}

Both districts have similar development strategies in that they propose moving toward serving niche fashion markets, particularly among local designers, with a production capacity that emphasizes smaller-scale projects and quick and flexible production. While having quick and flexible supply chains has, in one form or another, has been the conventional wisdom for apparel industry survival since the 1990s (Abernathy et. al., 1990; Berg et al., 1996), what is new in these proposals is a strategy that links supply chain reforms with specific product specializations and district-specific externalities.

The New York City study recommends that the district concentrate on higher-fashion products, which in general involve higher-quality fabrics, smaller production batches, and more craft-like skills than casual fashion products. Haute couture fashion "houses" mobilize high-level designers to develop seasonal collections that evolve over months from preliminary sketches to final templates and result in customized products. Ready-to-wear collections and lower-tier designer and "bridge" products are derived haute couture fashions, but have progressively simpler designs, less costly fabrics, lower price points, and larger markets. In all cases, manufacturing is held to high-quality standards and manufacturing speeds and schedules for delivery to buyers need to be quick.

New York already has established specializations in higher-fashion lingerie, dresses, and women's suits and coats. The field research in 2003 found that the median firm in the sample was mainly a producer of "better" products and about one third of the firms were producing “designer" products and high-end collections. Since then, New York appears to increasing its presence in these markets (Municipal Art Society of New York, 2011; Williams and CurridHalkett, 2011; Doeringer, 2012).

New York also has a stockpiled capacity to move up the fashion ladder. During the field interviews, suppliers were asked about both the fashion level of their current production and their ability to manufacture more fashionable products. The survey found that over $80 \%$ of the suppliers in the sample producing budget products could produce "better" quality products, half could supply bridge and designer-quality products, and one could even do haute couture collections. Although the skills needed to move to higher-fashion products increase at each level 
of fashion, two-thirds or more of the suppliers were capable of producing at least a one step higher level of fashion and half were capable of moving up two levels or more on the fashion ladder. These high levels of unutilized capacity for fashion production are an indicator of the ability of the New York district to shift production towards more fashionable market niches.

The data also show that, as apparel demand fell in the district, New York manufacturers and contractors that were capable of fashion production that were adding products with lower fashion content to their production mix. This finding suggests that the efficiency incentives derived from jobbers keeping core contractors in business are partly being sustained by combining orders of low-end products with fashion products.

By comparison, the Los Angeles studies recommended that the district move to "fastfashion" production. Fast fashion products are attuned to the most recent, and often the most transitory, fashion trends and their market consists largely of teenagers and young women who want stylish apparel at a reasonable price that can be affordably replaced as fashions change. Fast fashion products have a very short life cycle and new products are introduced throughout the season to maintain consumer interest and to replace popular products as soon as inventories are depleted. Fast fashion products are design-intensive in the sense that designs must be developed continuously and in large numbers throughout the year. New designs are quickly market tested and those that show promise are produced in larger quantities and rushed to market.

By aligning themselves on different sides of the "fashion divide" between high-quality, well-designed and more expensive products and lower quality and less expensive fast fashion products, New York and Los Angeles are acknowledging the subtle differences in their district externalities. The focus in New York is on fashion products where quality is more important than price and which require skilled design and manufacturing labor as well as fast and flexible supply chains. While New York can design and produce lower-end products quickly, and in large quantities as needed, the comparative advantage of the district lies in more fashionable products. It has pools of higher-end design talent and core manufacturing labor with experience in the production of fashion products that require greater skill, better quality of sewing, and greater care in the handling of costly fabrics than do fast fashion products, and its core jobber-contractor 
networks encourage the development of the kinds of manufacturing skills, tacit production knowledge, and problem-solving capacity essential for fashion products.

Differentiating their products by level of fashion and their districts by different types of buyers, suppliers, labor pools, and supply chain organization will place the New York and Los Angeles districts on different trajectories for the future. Both will benefit from having projectbased production capacities that can serve smaller niche markets, but only New York is returning to its original artisanal occupational systems and specialized contracting networks where it can tap the district's externalities of fashion designs, work force skills, and embedded efficiency relationships between jobbers and contractors. In contrast, the Los Angeles district will pursue a more industrial model based on advantages of speed, price, and the incentives of arms-length competition.

\section{Case Study II}

The Motion Picture, Television, and Video Industry: Developing a Cluster in Massachusetts

The film and television industry is viewed by some economists (Vogel, 2007: 71-72) as a model for the emerging network economy because of its reliance on project-based production systems (see also DeFillippi \& Arthur, 1998; Jones, 1996; Starkey et al., 2000; Windeler \& Sydow, 2001). There are two NAICS codes for the production side of the film and television industry, NAICS 51211(motion picture and video production), which captures the technical workers who produce films and television shows and NAICS 51219 (post-production and other) that captures technical activities, such as editing, titling, and special effects that occur after filming has taken place. Movie production was once the main specialization of the industry, but has been declining as television has become the major market for movies and videos, and because Canada has gained an increasing share of feature film production (Christopherson, et al., 2006).

U.S. production has long been concentrated in two locations, Los Angeles and New York City, with Los Angeles being the dominant location. The share of production by type of product and location varies considerably from year to year, but California accounted for over half (54.5\%) of all employment in 2010, compared to $20.5 \%$ for New York. Television is now the largest specialization in both Los Angeles and New York City, followed by feature films and 
then commercials (Christopherson, et al., 2006). The remaining 25\% of employment is apportioned among the rest of the United States, with the 10 largest states (excluding California and New York) accounting for around $44 \%$ of this employment.

\section{Producing films and television shows}

No two films or television shows will be produced in exactly the same way by exactly the same people. Rather, each film or television program is a unique creative project that is assembled by teams of freelance employees and service organizations that shift from project to project. There are also important differences in the ways that different kinds of products in this industry are made. Despite all these variations, we can identify some general stages of film and television production that help explain the industrial and occupational structure of this industry.

Perhaps the most important aspect of film and television production is the fact that it is an industry organized by contracts among relatively independent freelance employees who assemble on an as needed basis for each project. In practice, this means that each stage of production requires the assembly of a unique set of inputs of labor, financial, and material resources that are governed by a combination of short term contracts and dense social networks among members of craft based occupations. These inputs are assembled in stages related to the degree of completion of each project that are coordinated by a complex set of organizations and key personnel.

As Caves (2000) points out, film production typically begins with the acquisition of the rights to a story or other intellectual property. This intellectual property then becomes the content around which projects are developed and project teams are assembled. Because commercial motion picture and television projects often involve substantial upfront costs and subsequent revenue streams are uncertain, the first stage of production typically involves fundraising and the negotiation of terms under which this financing will take place (such as assignment of rights and future income streams).

Once financing is obtained, a project moves into a pre-production phase when the key members of the production team (director and star actors, supporting cast, and leaders of production crews) will be secured. This stage also involves the selection of production locations and processes (e.g., will shooting be done on soundstage or on-location), the development of budgets, script refinement, and other technical decisions. 
As projects move from pre-production to production, high initial costs are incurred as teams of technical and creative people are put to work in a studio or on location. The large number of employees involved in film production and the fact that they are typically governed by labor guidelines that increase costs if there are delays means that projects at this stage are particularly vulnerable to cost overruns and other risk factors.

The final stage in making a film is post-production. In this stage, raw footage is edited and assembled into a final narrative, music is selected or recorded, special effects and titles are added, and the final product is assembled for distribution.

\section{$\underline{\text { Industry Structure }}$}

The film and television industry has traditionally been associated with a highly concentrated, oligopolistic structure, and the motion picture industry in particular has been dominated by a few major Hollywood studios (Currah, 2007; Storper, 1989). Although film production is at its core a project based industry, for the first half of its history these projects were managed by a small number of vertically integrated studios that controlled almost all aspects of film production, distribution, and exhibition. Indeed, until the early 1950s, the Hollywood studio system relied on long term contracts and large, vertically integrated production, distribution, and exhibition systems. Several events led to a dramatic shift in this system beginning in the 1940s leading to an increased reliance on short term contracts among complex networks of freelance employees and small film service companies (see Caves, 2000: 87-102 for an excellent overview of this process).

Because it produces "experience" products, film and television production faces all of the traditional problems associated with creative industries including demand uncertainty, excess supply of creative inputs, skewed distributions of wages and profits, and vertically differentiated labor pools (Caves, 2000). One of the primary functions of project based mechanisms like MOSs, OLMs, and agglomeration economies is to mitigate the problems associated with project based production in creative industries. Because film and television production is both contract driven and involves high degrees of uncertainty and unique combinations of inputs, this is a setting in which governance problems are likely to arise. In the absence of organizational structures, social networks help to coordinate and govern these transactions (Jones, Hesterly \& Borgatti, 1997). 
For example, vertically-differentiated occupational labor markets (e.g. distinctions between A list vs. B list personnel) help reduce uncertainties about the future performance of workers. Social networks among freelance employees organized in OLMs allow these industries to assemble complex creative products because they help decision makers identify and assemble appropriate teams and help these teams coordinate by providing role clarity and governance functions (Jones, Hesterly \& Borgatti, 1997; Foster, Borgatti \& Jones, 2011). These network structures are typically coordinated by film producers and production firms (Starkey et al., 2000; Windeler \& Sydow, 2001; Sydow \& Staber, 2002; Manning, 2005), and these structures get reproduced on a project-by-project basis, which allows project participants to pursue projectbased careers (Jones, 1996) and become members of core project teams or preferred partner pools (Manning, 2010; Manning \& Sydow, 2011). In other words, instead of moving up career ladders within a single organization, employees in this sector move up inter-organizational career ladders made up of individual projects that provide valuable experience and reputation.

During World War II, movies stars began to form their own production companies (Caves, 2000:92). The studios accommodated this move and ended the long term contracts that had bound actors to specific studios. During the same period, the United States Department of Justice began a series of anti-trust cases against the film industry due to its domination of theatrical exhibition. In 1948, this litigation culminated in a court order forcing the industry to divest its theatrical exhibition businesses. Thereafter, studios were less focused on producing high volume (and lower quality) films to fill their many theaters and began to focus on producing smaller numbers of higher quality products. The nearly simultaneous arrival of television, which provided direct competition for movie going audiences, also contributed to this shift toward smaller numbers of higher quality, more creative products (Caves, 2000:94). These trends began the use of short term contracts among freelance employees and small service organizations that continues to this day.

Although the financing and distribution of films and television shows is still controlled by six major Hollywood studios (Vogel, 2007; Currah, 2007), the actual production of these creative products now takes places through a highly decentralized series of interlocking networks of freelance labor pools and small, specialized service organizations that are assembled on a project-by-project basis. 


\section{$\underline{\text { Labor Market Structure }}$}

Motion picture and television projects draw upon loosely coupled networks - sometimes called 'project networks' - for their labor, services, and materials. These networks coalesce temporarily around specific productions and shift from production to production (e.g. Windeler \& Sydow, 2001; Manning, 2005; Manning and Sydow, 2011).

An understanding of the occupational categories in the film and television industry and how they combine in different types of productions is critical for understanding the industrial and regional dynamics of this industry. Occupations in this industry are divided into two broad categories: "above-the-line" creative personnel and "below-the-line" production employees. In each of the occupations within these categories, relatively senior people assemble crews who work together on a semi-regular basis and move from project to project. For example, a director of photography will regularly use the same first cameraperson who may in turn have a preferred list of second camera operators and other crew members. These crews may be based within a single region, or they may take assignments that are being filmed on location in other regions.

\section{Above the Line Employees}

Above-the-line occupations include writers, directors, actors, producers and the like. While this category contains the small number of highly paid employees like star actors and directors, the majority of actors and creative workers are paid standard industry wages.

Unions have historically been relatively strong in the industry, particularly in feature film and dramatic television production, and above the line employees are organized through their own unions and trade groups (e.g., The Screen Actors Guild (SAG), American Federation of Television and Radio Artists (AFTRA), the Writers Guild of America and the Directors Guild of America. There are also many are freelance employees, most of whom are also members of the union (Caves, 2000). These occupation-based unions reinforce and support the occupational structure of the labor markets within the industry.

Innovations in compensation systems developed by the above the line unions in conjunction with the producer's multi-employer bargaining association (Alliance of Motion Picture and Television Producers - AMPTP) have made the unions indispensable to both their members and employers (Paul and Kleingartner, 1994). In brief, a three tier system of compensation has been adopted that involves base minimum pay (allowing neophytes to gain 
experience and employers to evaluate them cheaply), individual personal service contracts (which allow highly-talented stars to negotiate for additional forms of compensation such as higher salaries, a percentage of the profits, deferred compensation, or sequential employment guarantees), and residual payments. The latter are payments to artists for subsequent use of films in secondary markets such as videocassettes, DVDs, and pay per view cable. These union compensation arrangements have allowed the industry and its creative workforce to adapt more easily to changes in products and technologies (Paul and Kleingartner, 1994), and even to foreign competition (Frommer, 2003).

\section{Below the Line Employees}

The employees who handle the cameras, lighting, carpentry, transportation, electrical work and other technical aspects of film production are in the "below-the-line" occupations. While smaller and independent productions sometimes rely on non-unionized employees, large studio productions almost always hire their technical (below the line) employees from one of two international unions, the International Alliance of Theatrical Stage Employees (IATSE) and the International Brotherhood of Teamsters (IBT). Of these two unions, IATSE has a much larger proportion of employees on a typical film or TV set.

IATSE is the primary union representing film, television, and theatrical employees in set construction and dressing, lighting, special effects, rigging, props, camera, sound, wardrobe, make-up, and hairstyling and includes occupations such as carpenters, electricians (gaffers), riggers (grips), camera operators, costume, hair and makeup artists, and other trades that do the technical work required to produce a film or TV show. Between 1967 and 2000, there was a 63\% growth in members with $90-95 \%$ of film production in the U.S using IATSE members

(Frommer, 2003) and our Massachusetts interviews report that this growth has continued through the 2000s.

The IBT represents the much smaller number of transportation employees that drive the trucks and other equipment used in film productions. Because it also represents transportation employees in larger local industries, film transportation workers represent a relatively small segment of total Teamster membership.

Technological Change and the Decentralization of U.S. Production

The geographic concentration of the industry in Los Angeles and New York City is largely due to the agglomeration effects of local institutions like film academies, talent agencies, 
and film producers that play an important role in tying creative communities as well as technical service providers to particular regions through building and maintaining webs of regionally embedded, professional and personal relationships (Grabher, 2004; DeFillippi \& Arthur, 1998; Jones, 1996; Sydow \& Staber, 2002; Windeler \& Sydow, 2001; Lampel et al., 2000; Hirsch, 2000).

Increasingly, however, this production is taking place in locations outside of the traditional clusters of Hollywood and New York (USDOC, 2001) and similar trends are occurring in television production (e.g. Starkey et al., 2000; Windeler \& Sydow, 2001). During the 1990s, with the development of digitalization, the production of films was no longer restricted to a particular geographic location (USDOC, 2001; Klowden, et. al., 2010). Dailies (the film shot in a particular day) can now be sent instantly electronically anywhere for review and editing in time for the next day's shoot. Even post-production film work can now be conducted anywhere in the world, reducing the geographical clustering advantages of the traditional film centers.

$\underline{\text { Industry Subsidies and the Decentralization of Production }}$

By the late 1990s, other states and other countries began to offer incentive programs designed to lure film and television productions away from traditional centers of production to new locations like Georgia, Louisiana, Massachusetts, Illinois, Pennsylvania, New Mexico and to countries like Canada, and Australia. The number of movies either wholly or partially filmed in California fell from 272 in 2000 to 160 in 2008 (Klowden, et. al., 2010). According to a recent newspaper report (Verrier, 2010) shooting days in Los Angeles were down 19\% between 2008 and 2009. Studies have documented similar declines in production in New York (Christopherson et al., 2006).

The growth of film and television tax credit programs in the United States that began in the early 2000s was a competitive response to programs that appeared somewhat earlier in Canada. In 1997, the Canadian government implemented the Production Services Tax Credit program which provided a refundable tax credit for $16 \%$ of the labor costs paid to Canadian residents during the production of qualified productions. With subsequent programs developed by individual provinces, producers could generate total tax credits of between $37 \%$ and $70 \%$ of qualified labor and non-wage spending on film and television productions. When combined with 
the relative strength of the US dollar in the late 1990s, these programs lured large numbers of U.S. film productions to Canada.

From its inception, the Canadian program attracted the attention of industry representatives in the United States and generated heated debates about the impact of so-called "runaway productions" (e.g., productions leaving for Canada) on the U.S. film and television industry (Monitor Company, 1999; Neil Craig Associates, 2004; USDOC, 2001). Recognizing the success of the Canadian programs and responding to industry lobbying efforts about the potential loss of an iconic American industry, states in the U.S. began offering similar programs in the early 2000s thereby joining Canada and an increasing list of international locations in competing for film and television projects.

The first regional tax incentive program in the United States was implemented in Oklahoma in 2001. Termed the "Compete with Canada Act," it provided a cash rebate for 15\% of Oklahoma sourced production expenses for productions over \$1million. By 2010, at least forty states (including California and New York) have implemented some kind of film and television industry incentive program. As these programs have proliferated, so have debates about whether they are successful and how to measure their impacts (Christoperherson, et. al., 2006, McMillan, et. al., 2008; Miller and Abdulkadri, 2009; Popp and Peach, 2008).

Table 2 shows the total annual employment in NAICS 5121 (Motion Picture and Video Production) in the top twelve states as of 2001. Examining this reveals several trends. First, it is clear that while California and New York still have the vast majority of film and television jobs in the country, there have been some major changes in employment trends in these two centers and a handful of potential regional clusters have begun to emerge. For example, employment in California increased by $25 \%$ between 2001 and 2010, but only by $4 \%$ in New York (Table 2). The next four states with the highest employment in 2001 (Florida, Illinois, Texas, and Utah) all experienced double-digit net job loss over the period, while the next four states experienced significant employment gains. The last two states, Ohio and Minnesota, also experienced significant employment losses. 
Table 2: Average Annual Employment 2001-2010: NAICS 51211 (Motion Picture and Video Production)

\begin{tabular}{|c|r|r|r|r|r|r|r|r|r|r|r|}
\hline & $\mathbf{2 0 0 1}$ & $\mathbf{2 0 0 2}$ & $\mathbf{2 0 0 3}$ & $\mathbf{2 0 0 4}$ & $\mathbf{2 0 0 5}$ & $\mathbf{2 0 0 6}$ & $\mathbf{2 0 0 7}$ & $\mathbf{2 0 0 8}$ & $\mathbf{2 0 0 9}$ & $\mathbf{2 0 1 0}$ & $\begin{array}{l}\text { \% Chg. } \\
\mathbf{2 0 0 1}- \\
\mathbf{2 0 1 0}\end{array}$ \\
\hline CA & 85,913 & 108,104 & 104,905 & 122,773 & 114,290 & 113,465 & 113,399 & 117,282 & 105,120 & 107,659 & 25.31 \\
\hline NY & 38,940 & 33,839 & 29,470 & 28,546 & 30,881 & 31,121 & 31,089 & 32,810 & 32,484 & 40,518 & 4.05 \\
\hline FL & 5,604 & 5,576 & 4,636 & 4,228 & 4,700 & 4,462 & 4,693 & 4,691 & 3,936 & 3,502 & $(37.51)$ \\
\hline IL & 3,396 & 2,889 & 2,584 & 2,477 & 2,640 & 2,594 & 2,577 & 2,667 & 2,411 & 2,307 & $(32.07)$ \\
\hline TX & 3,292 & 3,218 & 3,330 & 2,730 & 3,074 & 2,982 & 3,084 & 2,831 & 2,591 & 2,698 & $(18.04)$ \\
\hline UT & 2,643 & 2,478 & 2,364 & 1,904 & 2,142 & 1,817 & 1,281 & 1,356 & 1,203 & 1,118 & $(57.70)$ \\
\hline NJ & 2,262 & 2,185 & 2,042 & 2,410 & 2,715 & 2,852 & 2,842 & 2,629 & 3,259 & 3,145 & 39.04 \\
\hline GA & 2,195 & 2,638 & 2,038 & 1,936 & 1,976 & 1,834 & 1,867 & 1,935 & 2,604 & 2,486 & 13.26 \\
\hline PA & 1,885 & 1,766 & 1,773 & 1,741 & 2,026 & 1,957 & 2,162 & 2,598 & 3,354 & 2,809 & 49.02 \\
\hline MA & 1,753 & 1,471 & 1,285 & 1,187 & 1,124 & 1,295 & 1,299 & 2,440 & 2,672 & 2,164 & 23.45 \\
\hline OH & 1,745 & 1,425 & 1,118 & 992 & 866 & 887 & 825 & 874 & 798 & 802 & $(54.04)$ \\
\hline MN & 1,623 & 1,231 & 1,219 & 1,160 & 1,148 & 1,068 & 1,080 & 1,131 & 1,010 & 916 & $(43.56)$ \\
\hline
\end{tabular}

All of these states have incentive programs that presumably contributed to employment growth, but the majority of these states experienced job losses and when we compare these employment trends with the timing of incentive programs, it is clear that incentives are not the only factor driving employment. States with no incentive programs until late in the period (like California) had significant employment growth (25\%) while other states with older programs like Illinois (2003) and Florida (2004) experienced net job losses. In Massachusetts, film industry employment had been on the decline until 2006 when the state implemented a 25\% tax incentive program, but there was nearly a two year lag between the implementation of this program and job growth in 2008 .

Among this group of states, New Jersey, Pennsylvania, Georgia, and Massachusetts seem likely candidates for becoming future regional industry clusters of film, television, and video production by virtue of their sustained employment levels and long-term growth. As we will show below, Massachusetts provides a useful laboratory for exploring this hypothesis.

The Development of a Motion Picture and Television Cluster in Massachusetts

The Massachusetts film and television industry was on the decline in the 1990s, with total employment falling by a third between 1990 and 2005. It rebounded gradually thereafter and turned in a respectable growth rate of $23 \%$ between 2001 and 2010. According to data from both the Motion Picture Association of America (2009) and the Quarterly Census of Employment and Wages (QCEW), Massachusetts had captured a little over $1 \%$ of the total national spending on 
motion pictures and television productions in 2010. About half of this spending was for wages, almost $15 \%$ for location fees, around $3 \%$ for set construction, and the rest spread around a number of uncategorized expenses (Pitter, 2011). Throughout our analysis we will focus on the two major sectors of the motion picture and video industry, (NAICS 51211 and NAICS 51219).

\section{Aggregate Employment Trends}

Movie production in Massachusetts outperformed the national industry over the decade of the 2000s with an overall growth in employment of $23.4 \%$ compared to $14.2 \%$ for the United States. This growth was helped by industry incentives as employment in 2010 increased to 2,164 from 1,124 in 2005 just before the implementation of the state incentive program in 2006, an almost $93 \%$ increase compared to a $4 \%$ increase nationwide during this same period. However, Massachusetts employment fared less well in the post-production sector with a decline of $15.5 \%$ over the entire decade compared to a national decline of $6.2 \%$.

Employment in the post-production (NAICS 51219), however, tells a particularly interesting story that may be related to its linkages with studio films. After growing rapidly from 371 employees in 2005 to over 800 in 2008, employment in this sector dropped to 236 in 2009 and 196 in 2010 (Table 3). The period of substantial growth in the middle of the decade coincided with a flow of studio-based films being produced in Massachusetts, which allowed local companies to build connections with studios and organizations in Hollywood and New York. Interviews with industry representatives in 2009 suggested that this growth also included the hiring of large numbers of new employees, which may explain the drop in annual average salaries as new entrants are often paid lower wages and work fewer hours than veteran employees.

Table 3. Average Annual Establishments, Employment and Wages: 1998-2010

\begin{tabular}{|c|c|c|c|c|c|c|c|c|c|c|c|c|c|}
\hline Average Annual Establishments & 1998 & 1999 & 2000 & 2001 & 2002 & 2003 & 2004 & 2005 & 2006 & 2007 & 2008 & 2009 & 2010 \\
\hline Motion picture \& video production (51211) & 319 & 316 & 326 & 311 & 308 & 293 & 297 & 297 & 272 & 273 & 298 & 287 & 295 \\
\hline Postproduction \& other (51219) & 34 & 31 & 35 & 36 & 33 & 30 & 30 & 32 & 28 & 30 & 31 & 32 & 29 \\
\hline \multicolumn{14}{|l|}{ Annual Average Employment } \\
\hline Motion picture \& video production (51211) & 1,736 & 1,621 & 1,836 & 1,753 & 1,471 & 1,285 & 1,187 & 1,124 & 1,295 & 1,299 & 2,439 & 2,672 & 2,164 \\
\hline Postproduction \& other (51219) & 371 & 301 & 351 & 282 & 379 & 230 & 318 & 371 & 247 & 803 & 840 & 236 & 196 \\
\hline \multicolumn{14}{|l|}{ Annual Average Wages } \\
\hline Motion picture \& video production (51211) & 42,840 & 45,453 & 50,103 & 50,700 & 48,624 & 51,370 & 54,415 & 57,695 & 60,527 & 60,598 & 61,225 & 53,051 & 41,033 \\
\hline Postproduction \& other (51219) & 31,648 & 39,477 & 46,471 & 49,301 & 30,932 & 49,953 & 35,728 & 34,953 & 51,986 & 18,086 & 19,437 & 63,904 & 72,144 \\
\hline
\end{tabular}

Source: Bureau of Labor Statistics, Quarterly Census of Employment and Wages

The data reported in Table 3, however, underestimates aggregate employment in the industry. The QCEW does not include freelance employees, who are a large proportion of the 
workforce in this industry and there are also undercounts of employment in small firms that are not part of the unemployment insurance system. The motion picture and television production industry is dominated by small firms with $78 \%$ of the Massachusetts establishments being in the 1-4 size class and another $12 \%$ in the 5-9 employee category (there is only one firm employing over 100 workers) and the post-production sector is similarly dominated by very small firms (U.S. Census Bureau, 2008). ${ }^{14}$

The data in Table 3 also show that the number of establishments has declined, even as employment has grown during this decade. Interviews with industry representatives suggest that this may be due to the widespread use of freelance labor in this sector, which is often supplied through local film service companies. Because both motion picture production and the sector of independent artists tend to pay the highest wages, the changes in the mix between local labor and "imported" labor could contribute to the high fluctuations in reported earnings.

\section{Monthly Employment Variation}

Employment in both motion picture and video production and post-production jobs also experiences large fluctuations in employment from month to month (Charts 2 and 3). When average annual employment in motion picture and television production rose by $88 \%$ (from 1,299 to 2,439 employees) between 2007 and 2008, minimum monthly levels of employment only rose by $61 \%$, while the monthly maximum employment more than doubled (from 1,462 to 3,126). Fluctuations in monthly employment were even more dramatic in the postproduction sector, ranging from 230 to 1505 in 2007 and 314 to 2480 in 2008. The trends in peak-to-peak employment provide a rough measure of trends in the level of core employment in the Massachusetts industry.

\footnotetext{
${ }^{14}$ This corresponds to national numbers where $81 \%$ employ $1-4$ and $10 \%$ 5-9.
} 
Chart 2. Monthly employment in NAICS 51211: Motion Picture and Video Production

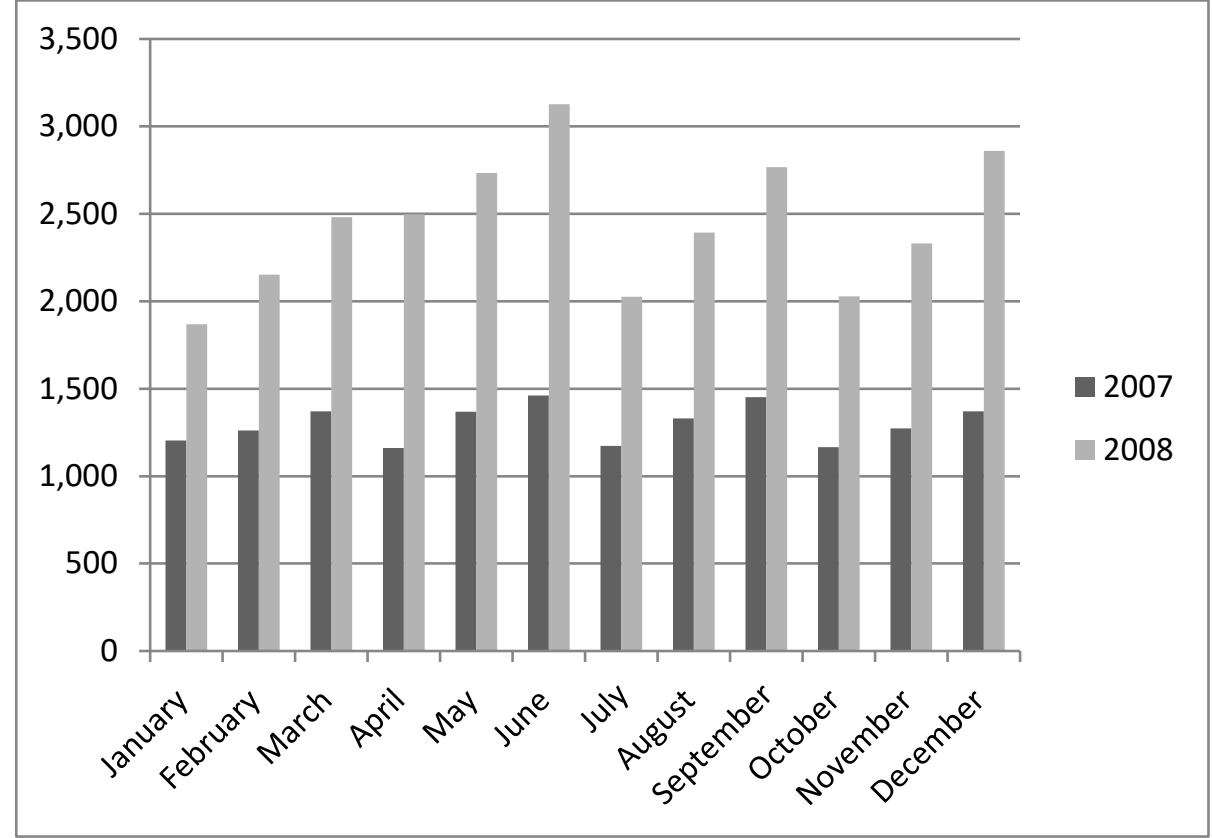

Source: Bureau of Labor Statistics, Quarterly Census of Employment and Wages

Chart 3. Monthly employment in NAICS 51219: Postproduction and Other

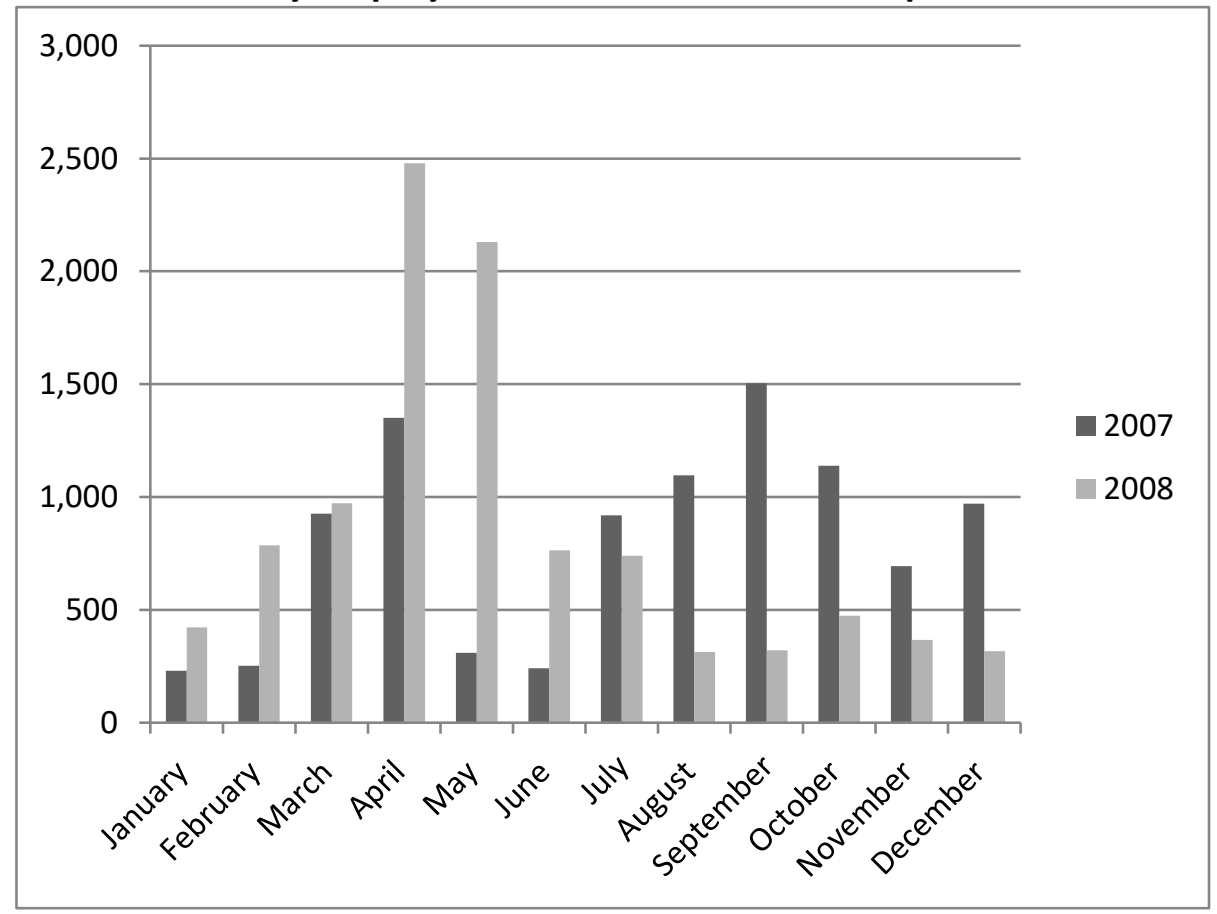

Source: Bureau of Labor Statistics, Quarterly Census of Employment and Wages 
These short-term employment dynamics can also help to explain the significant drop in wages in post-production in 2007 and 2008, as our interviews reported that a large number of temporary employees were hired at relatively low wages by large film productions in Massachusetts. Another factor in the earnings variability is the growth of the local non-fiction television and postproduction sector that has been hiring large numbers of relatively lower paid new entrants, many of whom are local college graduates who are seeking experience in local television production.

\section{The Effects of Project Mix}

Employment trends are also affected by the type of projects coming to Massachusetts and data from the most recent analysis of the Massachusetts film and television industry conducted by the Massachusetts Department of Revenue (Pitter, 2011) allows us to examine the effects of project mix on the industry in Massachusetts between 2006 and 2010 (Table 4). Because these data come directly from applications for the state tax credit (and because almost all commercial productions apply for the credit), they provide the most accurate picture of this industry available. 
Table 4. Film and Television Production and Spending in MA: 2006-2010.

\begin{tabular}{|l|r|r|r|r|r|r|}
\hline Category of Spending & 2006 & $\mathbf{2 0 0 7}$ & $\mathbf{2 0 0 8}$ & $\mathbf{2 0 0 9}$ & $\mathbf{2 0 1 0}$ & $\mathbf{2 0 0 6 - 2 0 1 0}$ \\
\hline Number of Productions & 95 & 122 & 159 & 97 & 83 & 556 \\
\hline Feature Films & 7 & 14 & 20 & 13 & 6 & 60 \\
\hline Commercials/Advertising & 45 & 53 & 86 & 51 & 51 & 286 \\
\hline Television Series & 26 & 29 & 28 & 21 & 14 & 118 \\
\hline Documentaries/Other & 17 & 26 & 25 & 12 & 12 & 92 \\
\hline & & & & & & \\
\hline Wages & $\$ 43.50$ & $\$ 111.10$ & $\$ 304.90$ & $\$ 203.60$ & $\$ 29.10$ & $\$ 692.20$ \\
\hline Wages \$1 Million \& Over & $*$ & $*$ & $\$ 133.60$ & $\$ 82.00$ & $*$ & $\$ 264.90$ \\
\hline Wages Under \$1 Million & $*$ & $*$ & $\$ 171.30$ & $\$ 121.60$ & $*$ & $\$ 427.30$ \\
\hline Non Wage Spending & & & & & & \\
\hline Set Construction & $\$ 1.20$ & $\$ 4.70$ & $\$ 23.70$ & $\$ 19.10$ & $\$ 1.50$ & $\$ 50.20$ \\
\hline Location Fees & $\$ 9.30$ & $\$ 10.50$ & $\$ 42.10$ & $\$ 36.60$ & $\$ 8.40$ & $\$ 107.00$ \\
\hline Unclassified/Other & $\$ 30.80$ & $\$ 30.10$ & $\$ 109.40$ & $\$ 74.10$ & $\$ 19.30$ & $\$ 263.70$ \\
\hline Total & $\$ 84.80$ & $\$ 156.50$ & $\$ 480.20$ & $\$ 333.40$ & $\$ 58.30$ & $\$ 1,113$ \\
\hline & & & & & & \\
\hline Of Which Spent on: & & & & & & \\
\hline MA Resident/Business (\$) & $\$ 29.90$ & $\$ 46.60$ & $\$ 153.00$ & $\$ 108.40$ & $\$ 36.70$ & $\$ 374.60$ \\
\hline Non-MA Resident/Business (\$) & $\$ 54.90$ & $\$ 109.90$ & $\$ 327.20$ & $\$ 224.90$ & $\$ 21.60$ & $\$ 738.50$ \\
\hline MA Resident/Busines (\%) & $35 \%$ & $30 \%$ & $32 \%$ & $33 \%$ & $63 \%$ & $34 \%$ \\
\hline Non-MA Resident/Business (\%) & $65 \%$ & $70 \%$ & $68 \%$ & $67 \%$ & $37 \%$ & $66 \%$ \\
\hline Source Massachusts Dart & & & & & \\
\hline
\end{tabular}

Source: Massachusetts Department of Revenue $\quad$ * Data not presented

Table 4 shows that the total number of productions peaked in 2008 and then dropped precipitously in 2009 and again in 2010 with feature films showing the greatest volatility. A feature film shooting in Massachusetts might employ hundreds of people for weeks at a time and spend tens of millions of dollars on various combinations of highly paid out of state employees (typically star actors), local and out-of state below-the-line employees, and service firms. As a result, these projects can have a disproportionate impact on local cluster development through both wage and non-wage spending patterns. Television commercials, by comparison, might have a local production budget of $\$ 250,000$ and employ a handful of actors and crew paid at standard union (or industry wages). During most of the 2006-2010 period covered by Table 3, project spending was divided roughly one third/two-thirds between Massachusetts and nonMassachusetts expenditures. However, when feature film production dropped in 2009 and 2010, not only did total spending fall rapidly, but the proportion of total industry spending on local employees and establishments increased from $33 \%$ to $63 \%$. 


\section{Labor Unions and OLMs in Massachusetts}

The national film and television industry is heavily unionized and feature films and television productions are made under contract with the major film and television unions. Smaller independent films and documentaries, commercials, and non-fiction television productions, however, are more likely to be non-union.

There are four international labor organizations that represent crew and cast employed on motion picture productions in Massachusetts: IATSE, SAG, AFTRA, and the IBT. These international unions maintain local chapters that cover their members while they are working in Massachusetts. These locals serve numerous functions including administrating the complex labor agreements that cover their members, tracking and administering member benefits, and helping to match employees with appropriate jobs and ensuring that there are enough properly trained local members to staff future productions.

Most large motion picture and television productions in Massachusetts are made by companies that have signed national agreements with IATSE or agreements with Local 481 specifically. IATSE represented employees make up a large proportion (up to 75\%) of the crew on film and television productions and its members constitute a disproportionate share of the experienced core workforce in the Massachusetts industry. A large fraction of these workers are members of IATSE Local 481 (http://www.iatse481.com), which represents the studio mechanic crafts in the New England states (Massachusetts, Rhode Island, New Hampshire, Vermont, Maine). ${ }^{15}$

Local 481's membership has grown dramatically in recent years, as film and television production has grown in Massachusetts. Local 481's Massachusetts's membership has more than doubled, increasing from 237 in 2005 to 585 in 2008 and there have been similar rates of membership growth in other Massachusetts IATSE locals. Pension fund data show that total annual wages earned in Massachusetts by Local 481 members increased ten-fold over the same period, from approximately $\$ 3$ million in 2005 to $\$ 30$ million in 2008 , which is a further indicator of increased continuity of employment of the core below-the-line workforce.

Local 481's membership has also increased in quality during this period of growth. Over the past few years, many Local 481 members have advanced from junior roles to become heads

\footnotetext{
15 The 15 crafts represented by Local 481 are Art Department Coordinators, Construction, Costume/Wardrobe, Craft Services, Electric/Set, Lighting, Greens, Grip, Locations, Medical/First Aid, Properties, Set Dressing, Sound, Special Effects, Teleprompter Operators, and Video Assist.
} 
of departments (on a particular project), a progression that now provides them with increased responsibilities and higher wages. Experienced members of other IATSE locals, formerly based in LA or NYC, who had family ties here or who had attended universities in Massachusetts, have also moved back to the Commonwealth to work on productions.

This development is important for several reasons. First, it has enhanced the ability of Massachusetts to support large productions with less need to import key workers from out of state. For example, on a recently filmed Adam Sandler movie ("Lake House") almost all of the departments represented by IATSE members were staffed locally from department heads down. One veteran of the local industry noted that the Commonwealth's crew base could now support 4-5 feature films at once, which was not the case two years ago, which is a remarkable increase in the capacity of this shared labor pool. Because of the structure of OLMs in film and television production, the development of local department heads is particularly important. Like general contractors in the construction industry, key employees select crews made up of people they are familiar with and trust. Because these people are more likely to be sourced locally, the localization of these key positions is a critical factor in workforce development in these sectors.

IATSE representatives report that some of these new members have migrated from related construction trades that have been experiencing significant employment contraction during the recession. There are numerous instances of carpenters who had been laid off or were underemployed in the construction industry transitioning to the motion picture industry, working steadily, and then joining Local 481. This is of particular note because it suggests that these sectors are able to absorb and rapidly retrain employees with similar skills from different occupations. It also points to the similarity of the technical aspects of film production to traditional crafts like construction. Some of these professions are so closely related that the definitions for the official government occupational codes for electricians (7-2111) and riggers (49-9096) list their corresponding film industry occupation titles (gaffers and grips) as "alternative occupation titles."

SAG and AFTRA both represent performers who appear in television shows and commercials while SAG alone represents performers who appear in motion pictures. Since motion picture production accounted for most of the recent increase in production in Massachusetts, recent workforce developments in the local branch of SAG are especially relevant to understanding the impact of these projects on the local workforce. The Boston branch 
of SAG grew by almost 30 percent between 2005 and 2008, with membership topping 2,100 by the end of $2008 .{ }^{16}$ There was a $58 \%$ increase in the total wage bill for feature films and television programming in 2008, as compared to $2005 .{ }^{17}$ The total spent on television commercials by members of SAG's Boston branch remained roughly constant between 2005 and 2008.

Although film and television employees represent a small proportion of Teamsters Local 25 's total membership of 11,500 employees, this group has also been growing rapidly. Prior to 2006, there were only 30 Teamsters employed in this industry, but by 2009 there were over 200 . In addition to the growth in total employment, there has been a growth in the total hours worked by these employees. As in the case of IATSE members, some of these new workers have come from other local transportation industries that have experienced recent contraction.

OLMs and Agglomeration Economies

Even with the significant growth in both the number and skill of local film production employees, there are still some crafts with too few employees who are experienced enough to staff key positions. In the middle of 2008, a local assistant director/location manager reported that some crew lacked experience working on large productions and expressed the need for more local senior crew in positions like costume and production design, special effects, directors of photography, digital image technicians, hair, and makeup. Other things being equal, film and television productions prefer to use a local crew because it saves the transportation and housing costs associated with importing talent. Because these key positions tend to hire people they have worked with before, as the Massachusetts crew base gains more experience and connections with out of state producers, we may find that the proportion of work on large films going to local crew will increase. This is a classic agglomeration economy one would expect to evolve from these OLMs.

The development of local crews who have a reputation for working together on certain types of projects is a key aspect of externalities developed in craft-like markets. Reputations and previous contacts become very important as a sorting mechanism for high quality labor and also as a barrier for new less experienced crews. Crews enhance their reputations and skill sets by

\footnotetext{
${ }^{16}$ SAG's reported membership is as large as the total workforce listed in the QCEW data in Table 3. This is largely due to the fact that SAG membership at any time will be larger than the total number of people currently employed on projects and that freelance employees are not included in the QCEW data.

${ }^{17}$ Data reporting practices SAG prevent the release of gross wages earned by local branches and only data trends are included in this report.
} 
working on different projects over time and workers have an incentive to essentially engage in their own cross training in order to enhance their attractiveness to potential project employers.

Film and television productions are material intensive and often require rapid service from local vendors. Therefore, the development of a cadre of experienced local service providers (such as in LA) is also important to servicing such a project-based industry. Often these vendors must rely on other sources of demand to survive the mercurial nature of film production schedules, but as film activity becomes more common they can shift more of their focus to this sector if it proves more lucrative.

\section{$\underline{\text { Film Production Specializations }}$}

Motion picture and video production is divided into a variety of specializations - feature films, television films and series, documentaries, student films, and music videos. Feature films are further divided between studio productions and independent productions and between "high budget and low budget films. Low budget films typically have much lower cast costs and a correspondingly higher percentage of costs devoted to below-the-line labor (Christopherson et al., 2006).

Feature films comprised only $10.8 \%$ of the productions in Massachusetts during the 2006-2010 period (see Table 4), but feature films have by far the biggest economic impact on the region because of their size and cost. Commercials and advertising represent the majority of the productions during this period $(51.4 \%)$ but create less value and employment per unit than other types of projects. Television series represent $21.2 \%$ of the region's projects, while documentaries constitute $16.5 \%$. The latter two specializations, but particularly documentaries, are most reflective of the region's central specializations. They rely on the same OLMs and utilize the same MOSs as feature films and their activities more -fully illustrate the nature of the overall film production cluster in Massachusetts. Interviews with industry participants and analysis of archival data helped us identify recent developments in these sectors.

\section{Television Production}

Compared to feature films, television productions (especially commercials and nonfiction programs) typically use a much smaller proportion of above the line talent. The television production sector in Massachusetts is itself comprised of at least three different sub-sectors. Dramatic and scripted television begins with the production of a pilot episode. Not all pilots become long running television shows. However, even shows that are picked up and air for a 
single season generate consistent employment for as many as one hundred cast and crew members. The 1980s television show, "Spencer for Hire," generated long-term jobs for many local television production employees. However, because scripted television is typically produced in a studio, Massachusetts currently lacks a critical resource for the growth of this sector. Respondents argued that without a studio, scripted television shows may continue to use Massachusetts as a backdrop for exterior shots (as the long running show "Boston Legal" did) but would find it difficult to produce a full show in the Commonwealth.

Non-fiction cable television production is currently the fastest growing and most profitable part of the television industry. This is driven by the fact that cable networks (as opposed to broadcast networks) can generate revenue from both advertising and carrier subscription fees. Moreover, as compared to scripted television, non-fiction television has lower production costs. Respondents report that there is significant room for international growth in this sector. Industry representatives suggest that Massachusetts has the potential to be the nation's third largest center for non-fiction television production. There are several factors that give Massachusetts a strategic advantage in this area. First, the labor pool contains experienced documentary producers, videographers, and sound recordists as well as a large pool of students who represent the potential for expanding this local labor pool. Only LA and NYC graduate more film/TV/video students annually than Massachusetts and many of these students are currently finding jobs in the rapidly growing local non-fiction television sub-sector.

Entry into the market for non-fiction television products is relatively easier than for feature movie production. In particular, non-fiction TV has many openings for production assistants, assistant editors, and researchers. These jobs also last longer than feature film jobs because the complete production cycle of one hour of prime time, non-fiction cable TV is between six and seven months long and career progression (such as to becoming an associate producer or producer) is also more rapid than in feature film production.

Massachusetts has two particular advantages that may contribute to the growth of this sector. First, it is home to the public television station $\mathrm{WGBH}$, which has long been recognized as a national center for non-fiction television production. In addition, the state is home to one of the national leaders (Avid Technologies) in video editing equipment as well as to a rapidly growing digital gaming industry. The combined presence of Avid Technologies, small special effects software developers, digital gaming companies, and leading research labs in artificial 
intelligence and emerging media (especially at MIT) represent a powerful set of potential synergies.

The, commercial and advertising sector is also starting to grow in the state. A majority of the television commercials produced in Massachusetts are made by a small handful of firms that reported that their overall business has remained stable between 2005 and 2008, a period when production of commercials in the U.S. as a whole has been on the decline. One advertising company reported that 70 percent of its commercials were produced in the Commonwealth in 2008 compared to only 40 percent in 2005 . However, Boston advertising agencies and large Massachusetts based advertisers (for example, Fidelity, New Balance, Gillette and Rebok) have still tended to use-out-of town production companies for most of their commercials. A local industry group called the Massachusetts Production Coalition has recently undertaken an aggressive campaign to encourage Massachusetts-based advertisers, such as TJX, to shoot their commercials in the Commonwealth.

\section{Documentaries}

Documentary filmmaking has long been a distinctive strength of Massachusetts. Many of the pioneers of 16-millimeter documentary filmmaking were based here, and WGBH's role as the flagship PBS station has allowed the Commonwealth to establish and maintain a leadership position in both series and long-form television documentaries. Documentaries are often made using grants and other donations and independent filmmakers rely on fiscal sponsors who provide the 501C3 (i.e., not-for-profit) status needed to qualify for major grants. While there are many fiscal sponsors in the Commonwealth, three of them in particular work with a large number of local productions and assist filmmakers in researching, applying for, and administering grants. Together, these organizations supported approximately 150 projects in 2009. The overall number of active projects reported by the fiscal sponsorships organizations has not increased significantly since 2005 and our interviews with sponsors and filmmakers indicated it was becoming increasingly difficult to raise money from major foundations. Funding in Massachusetts appears to have been relatively flat since 2005. The filmmakers interviewed reported that they typically shoot outside of state, while more often doing their post-production in-state.

While it is impossible to determine precisely how many independent documentary producers are working in the state, interviews with independent film makers and union 
representatives suggest that they likely outnumber independent narrative producers, a smaller but not insignificant group of local filmmakers. It appears that Massachusetts has the crew base and infrastructure to support a significant increase in independent narrative film production, but the funding for such projects remains unclear. Independent narrative films are either self-financed or financed by private investors, in contrast to the grants and donations typically used in documentary production. Investors are typically attracted to a narrative project if they believe the project will be financially successful and they will receive a return on their investment. Selffinancing is more common, and most independent filmmakers rely on other income sources to finance their independent films. These filmmakers also often work in film-related sectors including industrial, educational, and cable television production.

Because independent narrative filmmakers do not typically have fiscal sponsors, it was not possible to get the same broad view of narrative production over the past five years as was possible with documentary production. However, the number of low budget feature films shot under SAG agreement in Massachusetts doubled in recent years, rising from 18 in 2005 to 37 in 2008. The number of student films shot under SAG agreement more than doubled, going from 16 in 2005 to 41 in 2008. Although these kinds of projects do not make a large economic impact in the short term, they are important for developing young talent. In particular, young directors who achieve early success in Massachusetts may choose to shoot some or all of their future projects in the Commonwealth. Indeed, successful local actors like Ben Affleck have recently returned to the Commonwealth to produce films here.

Additional Externalities

Boston is a major cultural and creative center with active performance groups and a concentration of cultural knowledge at its numerous universities and museums. It has a wide range of visually-important filming locales and large pools of expertise in various film and television-related areas and it appears to have advantages in labor costs over Los Angeles and New York City, particularly in below-the-line occupations.

\section{Academic-based Education Programs}

Boston is an important center for students studying the production of film, television and other media. The Massachusetts College of Art and Design, Emerson College, Boston University, Fitchburg State, Curry College, and Bentley University all have film and television programs, some of which are important feeder schools for Los Angeles and New York City 
television and film companies. Boston University alone has over 1,000 students enrolled in Communications and Film and Television programs and in 2009 graduated almost 300 students from these programs. Many other local schools also have drama, film, and television courses and generate many young local employees seeking jobs.

Until recently, graduates of these programs typically faced the choice of leaving Massachusetts or giving up on a career in the film industry. School officials associated with these programs and other industry representatives report that alumni who had left for Los Angeles and New York City have recently returned to Boston as more employment opportunities have opened up in the film industry here. Moreover, as noted above, local production companies are employing an increasing number of these students as interns and providing career advancement opportunities for Massachusetts's college graduates. In addition to providing a local work force for the industry, these programs also provide part-time employment for the many senior members of the local film and television industry, which helps maintain a local labor pool of skilled workers during a decline in film projects. Industry representatives described these educational resources as a unique strategic advantage for Massachusetts.

Career opportunities for local graduates seem particularly promising in non-fiction television production where there are numerous examples of local university programs providing both interns and new entrants (e.g., production assistants, assistant editors and researchers) for local television and post-production companies. Moreover, the jobs in this specialization tend to last longer than those in feature films, because the production cycle is longer.

\section{Availability of Service Vendors and Suppliers}

A more recent promising development for the film cluster in Massachusetts is that local vendors, such as those supplying electrical products, for large film productions have been expanding their offerings and several national firms have opened Massachusetts offices. Similarly, the recent merger of two local equipment rental firms (Rule and Boston Camera) has created a Massachusetts-based firm that possesses the scale to serve large studio productions. A national catering firm, Hat Trick, has also opened an office in Massachusetts, filling a significant gap in the local industry's capabilities and suggests that key service firms see the location as promising. In addition, Media Services, one of a small number of national payroll companies that serves the motion picture industry, acquired CrewStar, a Massachusetts-based payroll firm. 
These trends suggest that there is a growing core of local film and television service firms emerging in the Commonwealth.

\section{$\underline{\text { Labor Costs }}$}

In addition to the advantages of abundant labor pools and flexible OLMs, Massachusetts appears to have a labor cost advantage over major production centers in six major production and post-production occupations for which comparable data are available (Table 5). The (unweighted) average wage for these occupations in the Los Angeles area is $48 \%$ higher than in Boston and $18 \%$ higher in New York area. ${ }^{18}$ The only occupation where Boston is more expensive is for camera operators, which receive lower pay in both New York and Los Angeles.

Table 5: Wages in Film-Related Occupations by Metropolitan Area, 2010

\begin{tabular}{|l|c|c|c|}
\hline \multicolumn{1}{|c|}{ Occupation } & $\begin{array}{c}\text { Boston } \\
\text { Wage }\end{array}$ & $\begin{array}{c}\text { New York City } \\
\text { Wage }\end{array}$ & $\begin{array}{c}\text { Los Angeles } \\
\text { Wage }\end{array}$ \\
\hline $\begin{array}{l}\text { Multi-media artist and } \\
\text { animators }\end{array}$ & $\$ 29.14$ & $\$ 32.73$ & $\$ 36.98$ \\
\hline Actors & $\$ 26.20$ & $\$ 27.35$ & $\$ 40.01$ \\
\hline Producers and directors & $34.12^{*}$ & $\$ 55.14$ & $\$ 66.66$ \\
\hline Writers and authors & $\$ 31.34$ & $\$ 43.98$ & $\$ 48.10$ \\
\hline Film and video editors & $\$ 30.59$ & $\$ 32.89$ & $\$ 44.74$ \\
\hline Camera operators & $\$ 33.96$ & $\$ 21.55$ & $\$ 32.16$ \\
\hline$*$ Massachusetts wage & & & \\
\hline
\end{tabular}

Source: U.S. Department of Labor, Occupational Employment Survey

\section{$\underline{\text { Intermediaries and Linkages between Massachusetts and Hollywood }}$}

One of the most important questions about the emergence of regional clusters in projectbased industries is whether, and how, they connect to more established clusters and the role local organizations play in connecting highly mobile projects with local labor networks and other resources. Local universities, movie industry unions, and government agencies can all play an important role in forging such links. Universities offer temporary employment for some industry employees as lecturers and also produce the labor for internships, temporary jobs, and more permanent occupations in the industry. The unions have helped connect local graduates with careers in the industry and have worked with the state to expand training opportunities.

\footnotetext{
${ }^{18}$ These numbers must be interpreted with caution. Some of the wage cost differences could reflect the different mix of skills used in the different regions within the same occupation. The higher wage costs in NYC and LA could be a function of the higher proportion of workers with advanced skills in these occupations.
} 
Our research also revealed the important role that was played by the Massachusetts Film Office (MFO) in the development of the local film and television industry and in connecting this local industry to highly mobile national productions. Originally opened in the mid-1970s, it was not until 1979 that the Massachusetts Film Office (MFO) began receiving significant state funding for the purpose of marketing Massachusetts as a location to national film and television productions. From the outset, its primary activities involved nurturing ties with creative talent outside the state, soliciting specific productions, and assisting them with location scouting and connecting them with other local resources such as the free use of public facilities for locations. Political support for the MFO waned in the 2000s and the MFO was dormant between 2002 and its reopening in 2007 following the passage of a new Massachusetts tax incentive program in 2005. While it is impossible to determine how much of this employment was driven by the marketing activities of the film office as opposed to the tax incentive, the activities of the MFO illustrate the kind of network building that can be done to link local networks of labor and other resources with national and international producers of film projects.

\section{$\underline{\text { Discussion }}$}

Massachusetts has experienced an uneven decade in its attempts to expand a motion picture and television production cluster within its borders. The state has little prospect of becoming a full-service region like Los Angeles and New York, but it has the ingredients for becoming one of a handful of "satellite" production concentrations that can compete for a growing share of below-the-line jobs for major feature films that need Massachusetts as a shooting locale. Except for "A level" actors and directors, it has ample capacity and what appear to be wage advantages in its labor pools to compete for low and medium-budget motion picture and television production and post-production work. There are signs of a growing core of experienced production crews and vendors with sufficient reputation to be substituted for "imported labor and suppliers" and it has a first class cultural and academic infrastructure that can provide expertise, part-time talent, and a flow of talented students to act, write, and support a variety of television products, independent films, and commercial videos. In addition, its unionmanagement relations are relatively free of conflict and it has sufficient tax incentives to level the financial playing field among other states aspiring to compete for "satellite" cluster status. It also has an "A level” producer of documentary films in its local NPR television affiliate. What it 
mainly lacks is the studio and sound-stage capacity for large-scale motion picture and made-fortelevision films and reliable sources of financing for independent narrative films.

Lessons from the Literature and Case Studies

Project-based production covers a wide range of manufacturing and service firms that participate in the production of one-of-a-kind or small-batch products. The production process for such products is uncertain because product development and production activities are intertwined. One example is "first-of-a-kind" prototype projects where the manufacturing and testing of the product often reveal design and development flaws that lead to project modifications and changing project specifications. Similar issues of production uncertainty and product modification arise more generally in project industries that produce highly-differentiated products with frequently-changing designs, as illustrated by the case studies of fashion apparel and motion pictures where products often evolve from initial conception to final product.

Production uncertainty, interactions between production and design, rapidly changing product designs, and quick turnaround times require labor that is both broadly-skilled and quickly able to identify and help resolve problems. Typically projects require workers with such skills to be able to work collaboratively in teams. Because the skills needed to produce projects are also subject to change as projects evolve, employment within the life of a single project team is fluid and the teams often change from project to project. As a result, project-based production often draws upon complex and "loose" networks of workers, contractors, and service vendors.

Project production is typically organized by a lead firm that recruits project teams and coordinates networks of specialized contractors - a general contractor in the construction industry; a jobber or a retailer in the apparel industry; or the producer in the case of motion pictures. Lead firms retain a "core" of experienced employees that perform these functions (and often participate in the production team as well) and they often draw upon a relatively stable "core" of contractors.

Project-based production is often time-sensitive because production delays result in lost markets or substantial increases in production costs. For example, prototype products are the preliminary step in a costly process of developing new products and opening new markets; samples are essential for securing orders in industries such as apparel where demand is seasonal 
and lead time-to-market is short; and failure to maintain production schedules for motion pictures can result in extra payments to above-the-line talent and below-the-line production crews who are idled by delays.

The intermittent and often time-sensitive demand in project-based firms and industries coupled with the need for broadly-trained and experienced labor pools and networks of reliable vendors and suppliers explain why project-based production is often concentrated in particular "districts" or regions that provide agglomeration economies tailored to support project-related activities. These districts provide an infrastructure for attracting and reinforcing clusters of project-based firms. Regional occupational labor markets in these districts complement the general skills and occupational structures of project-based production and the presence of such production allows them to retain the core of experienced workers and suppliers that is necessary to sustain it. Successful project-based districts also contain a variety of organizations - education and training institutions, professional and trade associations, and various government agencies and labor market intermediaries - that contribute to pools of knowledge through research, skill development, and the formation of network linkages. Silicon Valley, biopharmaceutical and lifesciences clusters around university research centers in Boston, San Francisco, and RaleighDurham, and the dominance of New York and Los Angeles in both apparel and motion picture and television production are common examples.

Whether or not the project-based model can help to revive the U.S. manufacturing sector rests in part on the ability of regions to help develop the externalities to facilitate such production. The logic for advanced economies having a comparative advantage in project-based production is that such production requires the kinds of human capital that is relatively more available in advanced economies than in those that are developing; that for some products the barriers of distance and transportation costs make time-sensitive production less vulnerable to import competition; and that the factor endowments, management capacity, and economic externalities present in developing countries lie more generally in mass production, rather than in smaller-scale niche markets. According to this logic, it is not surprising that the production of prototypes in advanced technology sectors or the small-scale production of replacement parts for older technologies should continue to be produced in the United States and that a number of project-based firms have competed successfully in global markets. What is more controversial is 
whether the United States can be competitive in project-based production in medium to low technology industries and for products with somewhat larger global markets.

Our case studies provide evidence that this may be possible by illustrating the labor force structures and intermediary institutions that can help make project-based industries successful. The case studies also provide clues on how local economic development policies can help provide the labor networks and institutions required for project-based industries to flourish. Establishing a well-educated workforce with flexible skills and abilities to work in teams is certainly a key component. In addition, helping to facilitate the development of networks among firms either through government institutions like the Massachusetts film office, or through unions as in the case of apparel, can also assist project-based industries in meeting their production needs.

The case studies also illustrate how clusters of project-based industries can create their own externalities to aid in their growth and/or survival. The apparel industry illustrates the vulnerability of low-technology, labor-intensive industries to competition from low-cost countries. However, the New York district has survived more than eight decades of decline, first as a project-based industry using highly-skilled and flexible labor and a pool of knowledge about fashion design to compete successfully against other U.S. garment districts with low labor costs. The district remained project-based as it grew, but it moved towards a network production model where lead firms (first manufacturers and then jobbers) coordinated specialized contractors to produce a wide variety of short-cycle products. This networking model eventually became the basis for mass production of fashion products, but as New York's labor costs increased relative to other districts, it was the more standardized and mass produced products that left the district while the more fashionable products with innovative designs and smaller production batches remained.

However, the longevity of the New York district depended as much on its ability to create new sources of district externalities as on its traditional externalities of knowledge of fashion and fashion design and the availability of skilled labor and flexible production methods needed for higher-end fashion products. The regulatory practices under collective bargaining initially helped to foster the production knowledge and problem-solving capacity of the district's core workforce and contracting networks and these externalities have been preserved as jobbers have assumed responsibility for regulating contracting relationships, with the decline in collective bargaining. 
Now that the combination of competition from imports and from Los Angeles has stripped away almost all of New York's relatively standardized and medium-to-large scale production, the district is left with the most time-sensitive products and the smallest market niches, many of which are at the higher end of the fashion scale. Having evolved from its startup phase as an artisanal craft industry serving a regional market for customized fashion products, through its industrial period of contracting networks operating at different levels of fashion and scale of production and serving national markets with a myriad of differentiated fashion products, and then through decades of maturity and decline, the district is now returning to its roots in craft-like production using core contracting networks and drawing upon both traditional and created externalities.

The motion picture and television industry in Massachusetts presents a different perspective on the interaction between project-based production and regional agglomeration economies. In this industry, it is Los Angeles, and to some degree New York City, that represent the production regions with well-established externalities. Massachusetts is one of several regions seeking to establish its own production cluster. At one level, Massachusetts is trying to attract production in standard ways by offering distinctive venues for feature films and television series, lower wages for some production occupations, and tax incentives that lower production costs. However, Massachusetts also has the advantages of a nationally recognized niche in documentary production a pool of independent film producers, a ready labor force graduating from local universities with well-rated motion picture and television schools or programs, and a union and government climate that can provide important externalities by serving as intermediaries for building local production capacity and providing linkages to motion picture and television producers in New York and Los Angeles.

While Massachusetts is unlikely to rival Los Angeles and New York in their pools of creative talent, well-trained below-the-line workers and vendors, and access to private and foundation financing for motion picture and television production, it is apparent that changes in industry structure and technology and the widespread availability of production subsidies are lessening the importance of the traditional agglomeration economies that have traditionally kept production in these districts. In the last decade, Massachusetts has gained considerable experience from having a number of feature films and television series filmed all or in part in the state and it is beginning to develop the kinds of core crews that are valued by outside producers 
and central to the success of its local documentary and independent producers. At the same time, national vendors and suppliers to the film and television industry have begun to trickle into the state; younger writers and directors who had been working in Los Angeles and New York are returning to Massachusetts, and filming of commercials has been growing in the state.

Collectively these developments suggest that Massachusetts is assembling an infrastructure that could support a diverse portfolio of motion picture and television businesses sufficient to establish the state as a viable satellite cluster for the industry.

\section{$\underline{\text { REFERENCES }}$}

Abernathy, F., J. T. Dunlop, J. H. Hammond, and D. Weil (1999). A Stitch in Time. New York: Oxford University Press.

Amin, A and N. Thrift (eds) (1994). Globalization, Institutions and Regional Development in Europe. Oxford University Press, Oxford.

Asheim, B.T. and A. Mariussen (2003). Introduction - why study temporary organizations? in Asheim, B.T. and A. Mariussen (Hrsg.): Innovations, regions and projects: Studies in new forms of knowledge governance. Stockholm: Nordregio, S. 7-11.

Atack, J. and P. Passell (1994). A New Economic View of American History from Colonial Times to 1940. New York: W. W. Norton \& Company).

Baker, W.E. and R.R. Faulkner (1991). Role as resource in the Hollywood film industry. American Journal of Sociology. 97 (2), S. 279-309.

Bechky, B. A. (2006). Gaffers, gofers, and grips: role-based coordination in temporary Organizations. Organization Science.17, 3-21.

Berggren, C., Söderlund, J., and Anderson, C. (2001). Clients, contractors, and consultants: the consequences of organizational fragmentation in contemporary project environments. Project Management Journal. 32 (3), S. 39-48.

Bigarelli D. (2000). L'habillement en Italie : PME et systèmes régionaux de production, in Bruno Courault and Phillipe Trouve (Eds.), Les Dynamiques des PME: Approches

Internationales. Paris: Presses Universitaires de France : 229-250.

Bigarelli, D. and P. Crestanello (2004). "Features and Changes in the Italian Apparel Industry," (mimeo) Istituto Poster, Vicenza, Italy, June.

Bonacich, E. and R.Appelbaum (2000). Behind the Label: Inequality in the Los Angeles Apparel Industry. (Berkeley and Los Angeles: University of California Press. 
Brusco (1982). The Emilian Model: Productive Decentralisation and Social Integration. Cambridge Journal of Economics. Vol. 6(2); 167-184.

Burt, R. S. (2004). Structural holes and good ideas. American Journal of Sociology. 110 (2), S; 349-399.

Carpenter, J.T. (1972). Competition and Collective Bargaining in the Needle Trades, 1910-1967. Ithaca, NY: New York State School of Industrial and Labor Relations, Cornell University.

Caves R. E. (2000). Creative Industries: Contracts between Art and Commerce. Cambridge, Harvard University Press.

Chandler, A. D., Jr. (1962). Strategy and Structure: Chapters in the History of the American Industrial Enterprise. Cambridge, MA: MIT Press.

Chinitz, B. (1961). Contrasts in Agglomeration: New York and Pittsburgh. American Economic Review, Vol. 51, 1961, pp. 279-289.

Christopherson, S. and N. Rightor (2010). The Creative Economy as "Big Business": Evaluating state strategies to lure film makers. Journal of Planning Education and Research, 29(3):336-352.

Christopherson, S., et.al. (2006). New York's Big Picture: Assessing New York's Position in Film, Television and Commercial Production. New York, NY: Cornell University.

Christopherson, S. and M. Storper (1989). The effects of flexible specialization on industrial politics and the labor market: the motion picture industry. Industrial and Labor Relations Review, Vol. 42, No. 3, April: 331-347.

Cicmil, S. and D. Hodgson (2006): Making projects critical: an introduction in Hodgson, D. and S. Cicmil (Hrsg.). Making projects critical. Basingstoke: Palgrave Macmillan, S. 1-25.

Copeland, C. (2010). Employee tenure trend lines, 1983-2010. EBRI Notes, Vo. 31, No. 12, December.

Currah, A. (2007). Hollywood, the Internet and the World: A Geography of Disruptive Innovation. Industry and Innovation, Vol. 14, No.4, September 2007: 359-384.

Davies, A. and T. Brady (2000). Organizational capabilities and learning in complex product systems: towards repeatable solutions. Research Policy, 29, 931-953.

DeFillippi, R.J.; M.B. Arthur (1998). Paradox in project-based enterprise: the case of filmmaking. California Management Review 40 (2), S. 1-15.

Dicken, P. (2011). Global Shift: Mapping the Changing Contours of the World Economy, Sixth Edition. New York: The Guilford Press. 
Doeringer, P.B. and D. G. Terkla (1995). Business Strategies and Cross-Industry Clusters. Economic Development Quarterly, Vol. 9, No. 3, August, pp. 225-237.

Doeringer, P.B., C. Evans-Klock, and D. Terkla. Start-Up Factories: High Performance Management, Job Quality, and Regional Advantage, Oxford University Press and W.E. Upjohn Institute for Employment Research, 2002.

Doeringer, P.B. and S. Crean (2006). Socioeconomic Review. Vol. 4, No. 3, pp. 353-377.

Doeringer, P.B., E. Lorenz, and D.G. Terkla (2003). The adoption and diffusion of highperformance management: lessons from Japanese multinationals in the West. Cambridge Journal of Economics, 27, 265-286.

Ebbers, J. and N. Wijnberg (2009). Latent organizations in the film industry: contracts, rewards, and resources. Human Relations. Vol. 62(7): 987-1009.

Eccles, R. G. (1981): The quasi-firm in the construction industry. Journal of Economic Behavior and Organization 2 (4), S. 335-357.

Economics Research Associates (2009). Louisiana Motion Picture, Sound Recording and Digital Media Industries. Chicago, I L: Economics Research Associates.

Ellison, G., E. L. Glaeser, and W.R. Kerr (2010). What causes industry agglomeration? evidence from coagglomeration patterns. American Economic Review. 100.3 June: 1195-1213.

Ernst and Young (2009a). Economic and Fiscal Impacts of the New Mexico Film Production Tax Credit. Ernst and Young.

Ernst and Young (2009b). Estimated Impacts of the New York State Film Credit. New York, NY: Ernst and Young.

Feldman, M.P. and J.L.Francis (2004). Homegrown solutions: fostering cluster formation. Economic Development Quarterly, Vol. 18,127-137.

Ferriani, S., G. Cattani, and C. Baden-Fuller (2009). The relational antecedents of project-entrepreneurship: network centrality, team composition and project performance. Research Policy,38, 1545-1558.

Feser,E., H.Renski, and H. Goldstein (2008). Clusters and economic development outcomes: an analysis of the link between clustering and industry growth. Economic Development Quarterly, Vol. 22(4), November 324-344.

Foster, P., Borgatti, S.P. and Jones, C. (2011). The contingent value of embeddedness:

Gatekeeper search in a local cultural market. Poetics. 39(4): 247-265. 
Foster, P., S. Manning, and D. Terkla (2011). The rise of Hollywood East: regional film offices as intermediaries in film and television production clusters. Working Paper, UMB College of Management.

Frommer, G. 2003. Hooray for... Toronto? Hollywood, collective bargaining, and extraterritorial union rules in an era of globalization. University of Pennsylvania Journal of Labor and Employment Law. Vol. 6(1): 56-118.

Galbraith, J. R. (1971). Matrix organization designs: how to combine functional and project forms. Business Horizons. 14 (1), S. 29-40.

Gann, D. M. and A. J. Salter (2000). Innovation in project-based, service-enhanced firms: the construction of complex products and systems. Research Policy 29 (7/8), S. 955-972.

Gereffi, G. (1994). The organization of buyer-driven global commodity chains: how U.S. retailers shape overseas production networks in Gereffi, G. and M. Korzeniewicz (Eds.). Commodity Chains and Global Capitalism. Praeger, Westport, CT.

Gereffi, G. (1999). International trade and industrial upgrading in the apparel commodity chain. Journal of International Economics 48 (1999) 37-70.

Giarratani, F., G. Gruver, and R. Jackson (2007). Clusters, agglomeration and economic development potential: empirical evidence based on the advent of slab casting by U.S. steel minimills. Economic Development Quarterly, Vol. 21, No.2, May,148-164.

Grabher, G. (2002a). Cool projects, boring institutions: temporary collaboration in social context. Regional Studies 36 (3), S. 205-214.

Grabher, G. (2002b). The project ecology of advertising: tasks, talents and teams. Regional Studies 36 (3), S. 245-262.

Grabher, G. (2004). Architectures of project-based learning: creating and sedimenting knowledge in project ecologies. Organization Studies 25 (9), S. 1491-1514.

Hagedoorn, J., A.N. Link, and N.S. Vonortas (2000). Research partnerships. Research Policy 29 (4/5), S. 567-586.

Haunschild, A. (2003). Managing employment relationships in flexible labour markets: the case of German repertory theatres. Human Relations 56 (8), S. 899-929.

Helfgott, R. B. (1959). Women's and Children's Apparel in M. Hall (ed). Made in New York. Cambridge: Harvard University Press, 1959. 
Hill, E.W. and J.F. Brennan (2000). A methodology for identifying the drivers of industrial clusters: the foundation of regional competitive advantage. Economic Development Quarterly, Vol. 14, No.1, February: 65-96.

Hirsch, P. M. (2000). Cultural industries revisited. Organization Science 11 (3), S. 356-361.

Hobday, M. (2000). The project-based organisation: an ideal form for managing complex products and systems? Research Policy 20 (7/8), S. 871-893.

InterVISTAS (2005). Film and Television Industry Review. British Columbia Ministry of Economic Development. October: 1-94.

Jackson, R. (1984). The Formation of Craft Labor Markets. Orlando, Florida: Academic Press.

Jacoby, D. (1991). The transformation of industrial apprenticeship in the United States. Journal of Economic History, Vol. 51, No. 4, December:887-910.

Jacoby, S. Employing Bureaucracy: Managers, Unions, and the Transformation of Work in American Industry, 1900-1945. New York: Columbia University Press, 1985.

Jones, C. (1996). Careers in project networks: the case of the film industry in M.B. Arthur and D.M. Rousseau (Hrsg.). The Boundaryless Career: a New Principle for a New Organizational Era. New York: Oxford University Press, S. 58-75.

Jones, C., Hesterley, W. S., and Borgatti, S. P. (1997). A general theory of network governance: exchange conditions and social mechanisms. Academy of Management Review.22 (4), S. 911945.

Keane, S. (2010). A State-by-State Guide to Business Incentives for Your Interactive Entertainment Production. Pillsbury Winthrop Shaw Pittman LLP.

Klowden, K., A. Chatterjee, and C. Hynek (2010). "Film Flight: Lost Production and its Economic Impact on California," Milken Institute, CA center, July.

Lampel, J., T. Lant, and J. Shamsie (2000). Balancing act: learning from organizing practices in cultural industries. Organization Science 11 (3), S. 263-269.

Lash, S. and A. Wittel (2002). Shifting new media: from content to consultancy, from heterarchy to hierarchy. Environment and Planning A 34 (11), S. 1985-2002.

Laubacher, R. (2006). Lens on the Bay State: Motion picture production in Massachusetts: Alliance for Independent Motion Media.

Levine, L. (1969). The Women's Garment Workers, New York. Arno \& the New York Times. 
Levine, L. and M. Levitan. Opportunity at work: the New York City garment industry. Mimeo, New York: Community Service Society of New York, 1998.

Lundequist, P. and D. Power (2002). Putting Porter into practice?: practices of regional cluster building: evidence from Sweden. European Planning Studies, Vol. 10, No. 6: 685-704.

Lundin, R. A and A. Söderholm (1995). A theory of the temporary organization. Scandinavian Journal of Management 11 (4), S. 437-455.

Manning, S. (2005). Managing project networks as dynamic organizational forms: learning from the TV movie industry. International Journal of Project Management 23 (5), S. 410 414.

Manning, S. (2008). Embedding projects in multiple contexts - a structuration perspective. International Journal of Project Management, 26 (1), 30-37.

Manning, S. (2010). The strategic formation of project networks: a relational practice perspective. Human Relations, 63 (4), 551-573.

Manning, S. and J. Sydow (2011). Projects, paths, and practices: sustaining and leveraging project-based relationships. Industrial and Corporate Change. 20 (5), 1369-1402.

Manning, S. and O. von Hagen (2010). Linking local experiments to global standards: how project networks promote global institution-building. Scandinavian Journal of Management. 26 (4), 398-416.

Marshall, A., Principles of Economics, London, Macmillan, 1890.

Martin, R. and P. Sunley (2003). Deconstructing clusters: chaotic concept or policy panacea. Journal of Economic Geography, Vol.3: 5-35.

McMillen, S., K. Parr, and T. Helming (2008). The Economic and Fiscal Impacts of Connecticut's Film Tax Credit: Department of Economic and Community Development.

Meyerson, D., Weick, K.E, Kramer, R. M. (1996). Swift trust and temporary groups in Kramer, R.M. and Tyler, T.R. (eds.) Trust in Organizations. Thousand Oaks: Sage, S. 166-195.

Midler, C. (1995). 'Projectification' of the firm: the Renault case. Scandinavian Journal of Management 11 (4), S. 363-375.

Miller, S.R. and A. Abdulkadri (2009). The Economic Impact of Michigan's Motion Picture Production Industry and the Michigan Motion Picture Production Credit: Center for Economic Analysis.

Mintzberg, H. and A. McHugh (1985). Strategy formation in an adhocracy. Administrative Science Quarterly. 30: 160-197. 
Monitor company. 1999. U.S. Runaway film and television production study report.

Montana, J.P. and B. Nenide (2008). The evolution of regional industry clusters and their implications for sustainable economic development. Economic Development Quarterly, Vol. 22(4), November: 290-302.

Motion Picture Association of America (2009). The Economic Impact of the Motion Picture \& Television Industry on the United States. Washington, DC: Motion Picture Association of America.

Motoyama, Y (2008). What was new about the cluster Theory? What could it answer and what could it not answer. Economic Development Quarterly, Vol 22(4), November:353-363.

Neil Craig Associates. 2004. International Film and Television Production in Canada: Setting the record straight about U.S. "runaway" production.

Newcombe, R. (1996). Empowering the construction project team. International Journal of Project Management.14 (2), S. 75-80.

Newlands, D. (2003). Competition and cooperation in industrial clusters: the implications for public policy. European Planning Studies_, Vol. 11, No.5, July: 521-532.

Osterman, P. (2000). Work reorganization in an era of restructuring: trends in diffusion and effects on employee welfare. Industrial and Labor Relations Review, Vol. 53, No. 2, January:179-196.

Osterman, P. (2006). The wage effects of high performance work organization in manufacturing. Industrial and Labor Relations Review, Vol. 59, No. 2, January.

Paul, A. and A. Kleingartner (1994). Flexible production and the transformation of industrial relations in the motion picture and television industry. Industrial and Labor Relations Review. Vol. 47(4), July: 663-678.

Perry, L. B., and R. S. Perry (1963). A History of the Los Angeles Labor Movement; 1911-1941. Berkeley and Los Angeles: University of California Press.

Piore, M. J., and C. F. Sabel (1984). The Second Industrial Divide: Possibilities for Prosperity. New York: Basic Books.

Pitsis, T. S. et. al. (2003). Constructing the Olympic dream: a future perfect strategy of project management. Organization Science. 14 (5), S. 574-590.

Pitter, A. (2011). A Report on the Massachusetts Film Industry Tax Incentives. Commonwealth of Massachusetts, Department of Revenue, November.

PMI (2000). A guide to the project management body of knowledge. PMBOK guide. Newtown Square, Pennsylvania: Project Management Institute. 
Pope, J.E. (1970). The Clothing Industry in New York, New York. (first printing 1905) Burt Franklin.

Popp, A. V. and J. PEACH (2008). The Film Industry in New Mexico and The Provision of Tax Incentives. Las Cruces, NM: Arrowhead Center, Office of Policy Analysis.

Porter, M. (1994). The role of location in competition. Journal of the Economics of Business. Vol.1(1): 35-39.

Reid, N, B.W. Smith, B.W., and M.C. Carroll (2008). Cluster regions: a social network perspective. Economic Development Quarterly, Vol. 22, No. 4, November: 345-352.

Rychen, F. and J.B. Zimmermann (2008). Clusters in the global knowledge-based economy: knowledge gatekeepers, and temporary proximity. Regional Studies, 42, 6, 767-776.

Sahlin-Andersson and A. Söderholm (eds) (2002). Beyond Project Management. New Perspectives on the Temporary-permanent Dilemma. Liber: Malmö.

Saxenian, A. (1996). Beyond boundaries: open labor markets and learning in Silicon Valley in M.B. Arthur and D.M.Rousseau (eds.) The boundaryless career: a new employment principle for a new organizational era. New York: Oxford University Press, p. 23-39.

Scott, A. (2006). Spatial and organizational patterns of labor markets in industrial clusters in B. Ashem, T. Cooke, and R. Martin (eds.) Clusters and Regional Development. Chapter 12. Routledge.

Shenhar, A.J. (2001): Contingent management in temporary, dynamic organizations: the comparative analysis of projects. Journal of High Technology Management Research. 12 (2), S. 239-271.

Shenhar, A. J. and D. Dvir (1996). Toward a typological theory of project management. Research Policy 25 (4), S. 607-632.

Slichter, S.H., J.J. Healy, and E.R. Livernash (1964). The Impact of Collective Bargaining on Management. Washington, D.C.: Brookings Institution.

Söderlund, J. (2000). Temporary organizing - characteristics and control forms in R.A. Lundin and F. Hartman (Hrsg.). Projects as Business Constituents and Guiding Motives. Boston: Kluwer Academic Publishers, S. 61-74.

Starkey, K., C. Barnatt, and S.Tempest (2000): Beyond networks and hierarchies: latent organizations in the U.K. television industry. Organization Science. 11 (3), S. 299-305.

Song, J., P. Almeida, and G. Wu (2003). Learning-by-hiring: when is mobility more likely to facilitate interfirm knowledge transfer? Management Science. 49(4): 351-365. 
Stinchcombe, A. L. (1959). Bureaucratic and craft administration of production: a comparative study. Administrative Science Quarterly. 4 (2), S. 168-187.

Storper, M. (1989). The transition to flexible specialisation in the US film industry: external economies, the division of labour, and the crossing of industrial divides. Cambridge Journal of Economics 13 (2), S. 273-305.

Sydow, J. and U. Staber (2002). The institutional embeddedness of project networks: the case of content production in German television. Regional Studies 36 (3), S. 223-235.

Teper, L. (1937). The Women's Garment Industry: An Economic Analysis. New York, International Lady Garment Workers Union.

Tolbert, P.S. (1996): Occupations, organizations, and boundaryless careers in M.B. Arthur and D.M. Rousseau (eds.). The Boundaryless Career: A New Employment Principle for a New Organizational Era. New York: Oxford University Press, p. 331-349.

Townley, B., N. Beech,and A. McKinlay (2009). Managing in the creative industries: managing the motley crew. Human Relations. Vol. 62 (7): 939-962.

Ulman, L. (1955). The Rise of the National Union: The Development and Significance of Its Structure, Governing Institutions, and Economic Policies. Cambridge: Harvard University Press.

U.S. Census Bureau (2008). County Business Patterns, Boston.

U.S. Department of Labor (2011). Occupational Employment and Wages. Bureau of Labor Statistics, Occupational Employment Statistics, May.

Uzzi, B. (2004). Collaboration and creativity: the small world problem. American Journal of Sociology 111 (2), S. 447-504.

Vernon, R. (1966). International investment and international trade in the product life cycle. The Quarterly Journal of Economics.80 (2): 190-207.

Verrier, R. (2010). Company town: L.A. location filming declines $19 \%$ in 2009 from previous year. Los Angeles Times: 3. Los Angeles.

Voegel, H. (2007). Entertainment Industry Economics. Cambridge: Cambridge University Press.

Whitley, R. (2006): Project-based firms: new organizational form or variations on a theme? Industrial and Corporate Change 15 (1), S. 77-99.

Windeler, A. and J. Sydow (2001). Project networks and changing industry practices collaborative content production in the German television industry. Organization Studies 22 (6), S.1035-1060. 
